\title{
21. STRATIGRAPHY AND SEDIMENTATION RATES FROM OXYGEN ISOTOPE COMPOSITION, ORGANIC CARBON CONTENT, AND GRAIN-SIZE DISTRIBUTION AT THE PERU UPWELLING REGION: HOLES 680B AND 686 ${ }^{1}$
}

\author{
G. Wefer, ${ }^{2}$ P. Heinze, ${ }^{2}$ and E. Suess ${ }^{3}$
}

\begin{abstract}
A high-resolution chronostratigraphy was established for Holes $680 \mathrm{~B}$ and $686 \mathrm{~B}$, drilled during Ocean Drilling Program (ODP) Leg 112 off Peru. The stratigraphy is largely based on oxygen isotopes of benthic foraminifers and supplemented by data for organic-carbon content and sediment texture. At both drill sites, during isotope Stage 1, the sedimentation rate was more than twice that of the older stages, which partly reflects lack of compaction in the youngest sediments. In Hole $680 \mathrm{~B}$, located at the center of a modern coastal upwelling cell in a water depth of 252.5 $\mathrm{m}$, the mean sedimentation rate is $6.6 \mathrm{~cm} / \mathrm{k} . \mathrm{y}$. in isotope Stages 1 through 15 . Hole 686B lies at the fringe of another active upwelling cell off Capo Nazca in a water depth of $447 \mathrm{~m}$. A prominent hiatus is evident between 105 and 120 $\mathrm{m}$ below seafloor (bsf). The mean sedimentation rate is $17.1 \mathrm{~cm} / \mathrm{k} . \mathrm{y}$. above the hiatus (isotope Stages 1 through 15 ) and about $100 \mathrm{~cm} / \mathrm{k} . \mathrm{y}$. below.
\end{abstract}

\section{INTRODUCTION}

A structural high on the outer shelf of the Peru margin delimits a series of depositional basins lying along strike of the convergent margin (Thornburg, 1985; and others). Portions of these basins underlie current centers of coastal upwelling (Suess and Thiede, 1983). The area at which sediments accumulate is between 150 and $450 \mathrm{~m}$ and lies within the well-developed oxygen-minimum zone (Reimers and Suess, 1983).

During Leg 112, six holes were drilled in these shelf basins (Suess, von Huene, et al., 1988b) (Fig. 1). The objective was to obtain a high-resolution record of the Quaternary to study the geological expression of coastal upwelling. In particular, variations in the depth of the oxygen-minimum layer caused by fluctuations in sea level were examined, as was the role of this layer in the accumulation and preservation of organic matter. To characterize both seaward-landward and latitudinal shifts of the upwelling centers, the drill sites were broadly oriented along an east-west transect crossing the margin, and a north-south transect parallel to the margin. Water depths of the drill sites intercepted where the present-day oxygenminimum layer impinges onto the bottom. Site 680 lies at the center of the sampling pattern defined by the two transects.

Site 680 is located within the present-day zone of maximum coastal upwelling (Suess, von Huene, et al., 1988a) and within the present-day core of a pronounced oxygen-minimum layer. Site 686 lies at the southernmost point of the north-south transect and at the fringe of the prominent upwelling cell around Capo Nazca. This area is characterized by high rates of sediment flux and subsidence. Thus, Site 686 was expected to provide a continuous, high-resolution record, whereas Site 680 , because of its shallower water depth, was expected to be more sensitive to Quaternary sea-level fluctuations.

Previously, we found that the distributions of calcium carbonate and, hence, the foraminiferal fauna, were discon-

\footnotetext{
${ }^{1}$ Suess, E., von Huene, R., et al., 1990. Proc. ODP, Sci. Results, 112: College Station, TX (Ocean Drilling Program).

${ }^{2}$ Geowissenschaften, Universität Bremen, Bibliothekstr., 2800 Bremen, Federal Republic of Germany.

${ }^{3}$ Oregon State University, School of Oceanography, Corvallis, OR 97331. Now at GEOMAR, Wischhofstr. 1-3, 2300 Kiel, Federal Republic of Germany.
}

tinuous downcore because of severe dissolution (Wefer et al. 1983); this was confirmed during shipboard work and severely limits the use of oxygen-isotope signals to determine an accurate chronostratigraphy. On the other hand, organic carbon is one of the most important constituents of these upwelling deposits and can be used in conjunction with the oxygen-isotope record to identify hiatuses or other abrupt changes of the environment of deposition and to bridge gaps where foraminifers are scarce or absent.

\section{LITHOLOGY AND ENVIRONMENTAL SETTING}

$$
\begin{gathered}
\text { Site } 680\left(11^{\circ} 03.90^{\prime} \mathrm{S}, 7^{\circ} 04.67^{\prime} \mathrm{W}\right. \text {; } \\
\text { water depth, } 252.5 \mathrm{~m})
\end{gathered}
$$

Sediments of the upper Pleistocene at this location are characterized by a sequence of laminated (millimeter to centimeter), dark gray, diatom-rich clays and silts having a high organic-carbon content. Intercalated within this sequence are gray, several centimeter-thick, clastic silt layers having a high terrigenous flux and containing thin phosphorite layers. The sequence at Site 680 represents Pleistocene coastal upwelling sediments that have undergone little or no reworking (Suess, von Huene, et al., 1988).

From magnetostratigraphic shipboard analyses, a mean sedimentation rate of $5 \mathrm{~cm} / \mathrm{k}$.y. was estimated for the upper Pleistocene. However, the sedimentary record has been disturbed by hiatuses in the lower Pleistocene, making these estimates somewhat tenuous. During the lower Pleistocene, the sediments display a greater terrigenous flux and contain phosphorite sands. Diatom and benthic foraminiferal assemblages and morphologies of species indicate intense upwelling and oxygen-minimum conditions of the bottom water. Cores from Holes $680 \mathrm{~A}$ and $680 \mathrm{~B}$ are well-correlated, based on lithostratigraphic and biostratigraphic markers, as well as on physical index properties and magnetic susceptibility (Shipboard Scientific Party, 1988a; Merrill et al., this volume).

$$
\begin{gathered}
\text { Site } 686\left(13^{\circ} 28.81^{\prime} \mathrm{S}, 76^{\circ} 53.49^{\prime} \mathrm{W}\right. \text {; } \\
\text { water depth, } 446.8 \mathrm{~m})
\end{gathered}
$$

The sediments at this site are of Quaternary age and consist of dark diatomaceous mud. In general, they contain more silty and sandy components than the sediments at Site 680 . From 


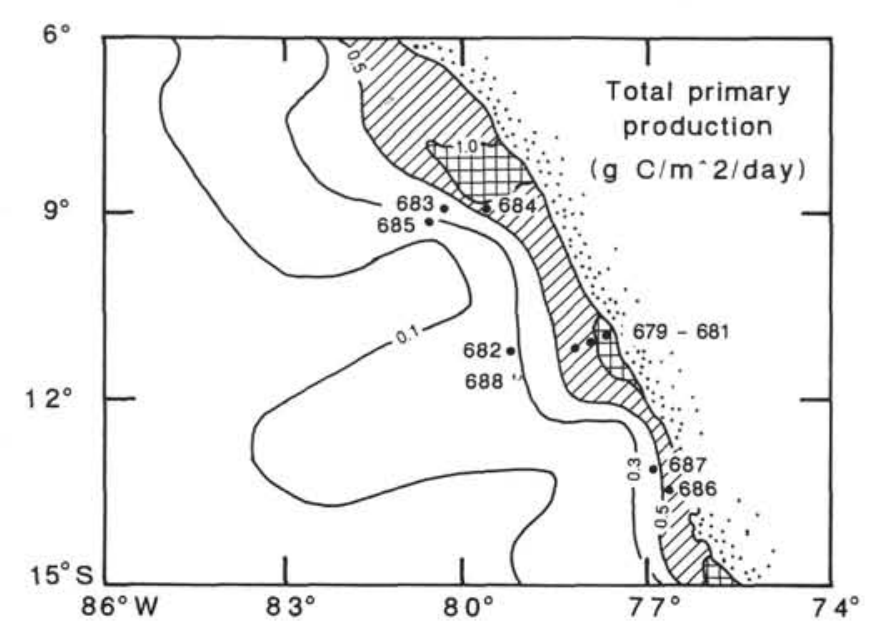

Figure 1. Upwelling centers along the Peru continental margin, as delineated by the maxima in integrated-mean, long-term primary production with positions (modified from Reimers and Suess, 1983) of sites drilled during Leg 112 . Shelf sites are located along north-south and east-west transects. Hole $680 \mathrm{~B}$ is at the intersection of the two transects, while Hole $686 \mathrm{~B}$ is at the southernmost point of the north-south transect.

biostratigraphic shipboard analyses a mean sedimentation rate of about $15 \mathrm{~cm} / \mathrm{k}$.y. was determined for Site 686 . This value is approximately three times higher than the sedimentation rate at Site 680 .

Three major laminated intervals alternate with three bioturbated intervals at Site 686 . The bioturbated sections commonly contain silty, sandy, and shelly beds (Schneider and Wefer, this volume). Intervals of intense upwelling are indicated by various diatom assemblages (Schrader, this volume). Changes in the species composition of benthic foraminifers downcore suggest a continual decrease in water depth with increasing age (Shipboard Scientific Party, 1988b). Cores from the two holes at this site were readily correlated on the basis of several markers and other sediment properties.

\section{METHODS}

Sediments from Sites 680 and 686 were sampled every 25 $\mathrm{cm}$. A subsample having a volume of $20 \mathrm{~cm}^{3}$ was available from each sample. Each subsample was split before processing and one-half $\left(10 \mathrm{~cm}^{3}\right)$ was used for carbonate and organic carbon determinations using Welikey et al.'s method (1983). This is a combined wet-oxidation acidification method in which carbonate carbon and organic carbon are discriminated and the evolved $\mathrm{CO}_{2}$ measured by thermal conductivity. The advantage of this method for the type of samples encountered during Leg 112 lies in its ability to measure widely varying amounts of organic carbon without interference from calcium carbonate. Grain-size and isotope analyses were performed on the other $10 \mathrm{~cm}^{3}$ of each sample. The samples were soaked in a borax solution $\left(\mathrm{Na}_{2} \mathrm{~B}_{4} \mathrm{O}_{7.10} \mathrm{H}_{2} \mathrm{O}\right)$ for $24 \mathrm{hr}$ and subsequently wet-sieved through a $63-\mu \mathrm{m}$ sieve. The $<63-\mu \mathrm{m}$ residue of each sample from Hole 686 was further subdivided by wetsieving, and the $32-$ to $63-\mu \mathrm{m}$ fraction dried and weighed. The $>63-\mu \mathrm{m}$ fraction was separated into the $63-$ to $125-\mu \mathrm{m}$ and $>125-\mu \mathrm{m}$ fractions, and the two resulting portions of each sample were weighed. These weights were used to determine the fractions of the individual size classes.

The benthic foraminiferal taxa were identified according to the specifications of Uchio (1960), Smith (1963), Resig (1981), and Matoba and Yamaguchi (1982). The only species that occurred in abundance throughout Hole $680 \mathrm{~B}$ and partway through Hole 686B was the benthic foraminifer Bolivina seminuda humilis. This is the key species of the Bolivina seminuda humilis Assemblage (Resig, 1981). Specimens that showed no trace of contamination were selected for oxygenisotope measurements. The mean number of individual tests per analysis in the size fraction from 125 to $212 \mu \mathrm{m}$ was 40 . The oxygen-isotope ratios were measured on a Finnigaan MAT 251 mass spectrometer connected to a fully automated carbonate preparation line (CARBO-Kiel, C-14 Labor, Christian-Albrechts Universität Kiel).

\section{RESULTS AND DISCUSSION}

\section{Site 680 -Stratigraphy}

Downcore oxygen-isotope variations in the benthic foraminifer Bolivina seminuda humilis are shown in Figure 2A. With the exception of two high values $(3.11 \%$ and $2.99 \%$ at 31.23 and $31.48 \mathrm{~m}$, respectively) and one low value $(0.80 \%$ at $1.64 \mathrm{~m})$, the $\delta^{18} \mathrm{O}$-values range between 2.72 and $1.29 \%$. Variations with depth exhibit the typical saw-toothed pattern observed in the $\delta^{18} \mathrm{O}$ records of deep-sea cores. The isotope curve exhibits many similarities to the standard isotope curves from deep-sea environments on the basis of planktonic foraminifers (Fig. 3). The standard isotope Stages 1 to 15 could be identified. Following the graphic method described by Prell et al. (1986), a correlation was established between the stage boundaries in Hole $680 \mathrm{~B}$ and the standard reference section (Fig. 4). In Table 1, the depths and ages of the stage and substage boundaries are listed together with sedimentation rates. The

Table 1. Depths and ages of stage and substage boundaries as well as sedimentation rates of Hole $680 \mathrm{~B}$.

\begin{tabular}{|c|c|c|c|}
\hline Stage & $\begin{array}{l}\text { Stage-boundary } \\
\text { (mbsf) }\end{array}$ & $\operatorname{Age}^{a}$ (k.y.) & $\begin{array}{c}\text { Sedimentation } \\
\text { rate } \\
(\mathrm{cm} / \mathrm{k} . \mathrm{y} .)\end{array}$ \\
\hline & 0 & 0 & \\
\hline 1 & 25 & & 20.8 \\
\hline 2 & 2.2 & 12.05 & 10.4 \\
\hline 3 & 3.8 & 24.11 & 5.0 \\
\hline & 5.5 & 58.96 & \\
\hline 4 & 6.6 & 73.91 & 7.5 \\
\hline 5 & 9.7 & 129.84 & 5.6 \\
\hline 6 & 13.9 & 189.61 & 7.0 \\
\hline 7 & 17.4 & 244.18 & 6.4 \\
\hline 8 & 19.4 & 303.00 & 3.4 \\
\hline 9 & 23.2 & 339.00 & 10.6 \\
\hline 10 & 24.9 & 362.00 & 7.1 \\
\hline 11 & 30.6 & 423.00 & 9.4 \\
\hline 12 & 31.7 & 478.00 & 2.0 \\
\hline 13 & 35.9 & 524.00 & 9.0 \\
\hline 14 & 37.1 & 565.00 & 3.1 \\
\hline 15 & 41.0 & 620.00 & 7.1 \\
\hline
\end{tabular}

\footnotetext{
a Ages were taken from Imbrie et al. (1984) and Martinson
} et al. (1987). 


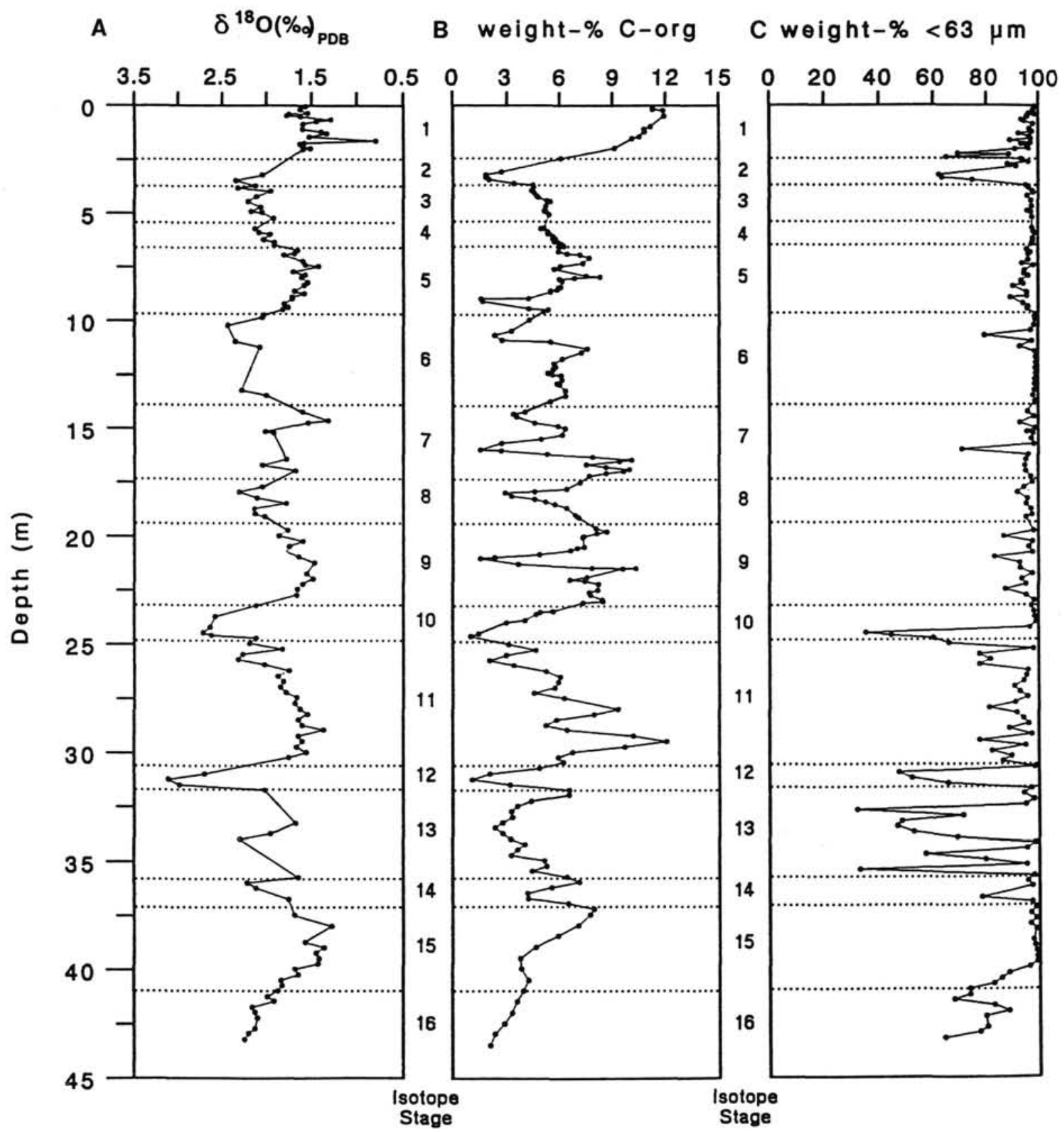

Figure 2. Downhole variations at Hole 680B. A. Oxygen-isotope composition of the benthic foraminifer Bolivina seminuda humilis. B. Organic carbon content . C. Grain-size distribution in Hole 680B $(<63 \mu \mathrm{m})$; note coarse-grained interval between about 32 and about $36 \mathrm{~m}$, indicating condensed section.

ages were taken from Imbrie et al. (1984) and Martinson et al. (1987).

Down to isotope Stage 12 a good correlation exists between the benthic isotope curve of Hole $680 \mathrm{~B}$ and the planktonic standard isotope curve of Imbrie et al. (1984). The correlation is not obvious for the core interval of isotope Stages 13 and 14 (Fig. 3). Below the well-developed $\delta^{18} \mathrm{O}$-maximum of Stage 12 $(31.50 \mathrm{~m})$ lies an interval with few oxygen-isotope measurements, strongly fluctuating organic carbon contents (see Fig. 2B), and coarse-grained sediments (Fig. 2C). The section between 31.50 and $34.80 \mathrm{~m}$ core depth is characterized by a diatomaceous mud interbedded with sand and silty sand, which grades upsection to mud. From smear slides, a sand content of up to $85 \%$ was estimated (Shipboard Scientific
Party, 1988a) and was confirmed by our analyses of grain size. The weight-percent of the $<63-\mu \mathrm{m}$ fraction indicates that this interval represents a highly condensed time section (Fig. 2C).

The Brunhes/Matuyama magnetic boundary was tentatively identified at a core depth of between 35 and $36 \mathrm{~m}$ in both holes of Site 680 (Shipboard Scientific Party, 1988a). However, there is some concern about this identification because of the rapidly diminishing magnetic intensity signal downcore and because the weak reversed polarities (on which the identification was based) were measurements of natural remanence, whereas the normal polarities were obtained after demagnetization, as is the usual procedure (Shipboard Scientific Party, 1988a). For these reasons we have not used the Brunhes/Matuyama magnetic boundary for our stratigraphy. 


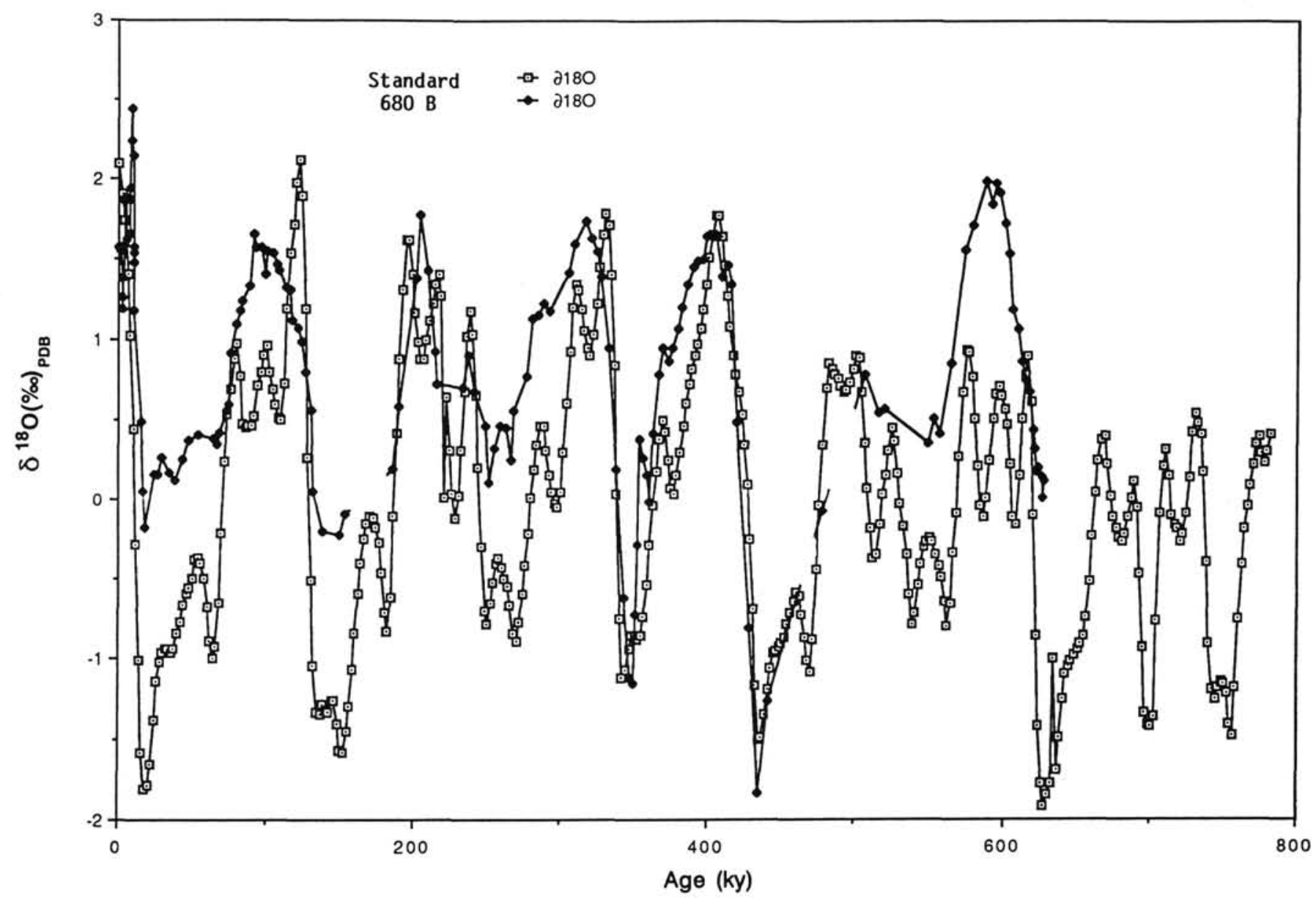

Figure 3. Comparison of Hole $680 \mathrm{~B}$ downhole variations in oxygen-isotope composition of the benthic foraminifer Bolivina seminuda humilis with standard isotope curve of Imbrie et al. (1984), which is based on pelagic foraminifers.

The upper Pleistocene sediments at Site 680 are rich in organic matter; the range of organic carbon contents is also extreme (Fig. 2B). Maxima lie between 10 and $15 \mathrm{wt} \%$, minima are $<1 \mathrm{wt} \%$, and mean concentrations are about 5.5 wt\%. Lower Pleistocene sediments contain distinctly less organic matter (data not shown here). For the scope of this paper, we have used the organic carbon distribution, particularly over intervals where benthic foraminifers are scarce, to support the boundary selections of the oxygen-isotope stratigraphy. In general, glacial sediments have low organic carbon contents and interglacial sediments have high organic carbon contents. This feature was particularly pronounced at and near the stage boundaries, i.e., terminations $1 / 2,5 / 6,7 / 8,9 / 10$, and $11 / 12$, whose depths in Hole $680 \mathrm{~B}$ were also constrained by the distribution of organic carbon. Another characteristic of the organic carbon record was the repeated, rapid, and short-term decrease in organic carbon contents at the heights of the interglacial stages.

\section{Site 686-Stratigraphy}

Downcore variations in the oxygen isotopes of the benthic foraminifer Bolivina seminuda humilis are shown in Figure 5A. At this site, insufficient specimens of Bolivina seminuda humilis precluded a continuous oxygen-isotope stratigraphy. Between a depth of 56.75 and $164.06 \mathrm{~m}$, however, enough specimens were available for analysis. The distinctively banded volcanic-ash layer at $154.53 \mathrm{~m}$ facilitated correlations between Sites 686 and 687 . The radiometric age of $1.42 \pm 0.06$ m.y. was determined; in all, three different dating methods were employed simultaneously:. conventional $\mathrm{K} / \mathrm{Ar},{ }^{40} \mathrm{Ar} /{ }^{39} \mathrm{Ar}$ total fusion, and ${ }^{40} \mathrm{Ar} /{ }^{39} \mathrm{Ar}$ stepwise fusion. Although two ash samples obtained from Hole 686B (Table 2) yielded significantly older ages than the three samples from Hole 687B (Table 2), overwhelming sedimentological evidence (in both holes a ca. $2 \mathrm{~cm}$-thick white layer is overlain by a several centimeter-thick light gray ash layer) indicates that these marker beds are equivalent at the two sites (Shipboard Scientific Party, 1988b, 1988c). We suspect that the ash layer at Site 686 contains older material and have assigned an age of $1.42 \pm$ $0.06 \mathrm{~m} . \mathrm{y}$. to the volcanic event that produced the characteristic layers.

Using the $\mathrm{K} / \mathrm{Ar}$ age of $1.4 \mathrm{~m} . \mathrm{y}$., we have assigned the oxygen-isotope cycles between 120 and $164 \mathrm{~m}$ to Stages 47 through 49 (Williams et al., 1988). Clearly, from the uncertainty of the radiometric age, this stage assignment is accurate only to \pm one complete climatic cycle. The sedimentation rate, however, can be more accurately determined. The shape of the oxygen-isotope curve from the depth interval 122 to 162 m clearly exhibits the 41 k.y. periodicity described by Ruddiman et al. (1986) for the Matuyama chron (2.47 to $0.735 \mathrm{Ma})$, which implies a sedimentation rate of about $100 \mathrm{~cm} / \mathrm{k} . \mathrm{y}$. We chose these stages because of similarities in shape to an isotope curve depicted in Williams et al. (1988). In both cases, the $\delta^{18} \mathrm{O}$ range between glacial and interglacial periods is about $1.4 \%$. Above Stage 47 and below Stage 49, the isotope range is much larger, reaching values of about $2 \%$. 
Table 2. Radiometric age of a volcanic ash layer present at $154.53 \mathrm{mbsf}$ in Hole 686B.

\begin{tabular}{|c|c|c|c|c|}
\hline $\begin{array}{l}\text { Core, section, } \\
\text { interval }(\mathrm{cm})\end{array}$ & $\begin{array}{l}\text { Potassium } \\
\quad(\%)\end{array}$ & $\begin{array}{l}\text { Radiogenic }{ }^{40} \mathrm{Ar} \\
\left(\times 10^{-7} \mathrm{~cm}^{3} / \mathrm{g}\right)\end{array}$ & $\underset{(\%)}{\text { Rad. }}{ }^{40} \mathrm{Ar}$ & $\begin{array}{l}\text { Age } \pm 1 \sigma \\
(\mathrm{Ma})\end{array}$ \\
\hline $112-687 \mathrm{~A}-6 \mathrm{H}-4,16-18$ & 3.909 & 1.99772 & 5.3 & $1.32 \pm 0.05$ \\
\hline $112-687 \mathrm{~A}-6 \mathrm{H}-4,11-14$ & 4.740 & 2.57684 & 28.7 & $1.40 \pm 0.02$ \\
\hline $112-686 \mathrm{~B}-17 \mathrm{X}-3,50-54$ & 3.473 & 5.26635 & 7.1 & $3.90 \pm 0.11$ \\
\hline $112-686 \mathrm{~B}-17 \mathrm{X}-3,54-56$ & 4.024 & 22.8973 & 49.3 & $14.60 \pm 0.2$ \\
\hline \multicolumn{5}{|c|}{${ }^{40} \mathrm{Ar} /{ }^{39} \mathrm{Ar}$ age determinations ${ }^{\mathrm{a}}$ for volcanic ashes from Leg 112} \\
\hline $\begin{array}{l}\text { Core, section, } \\
\text { interval }(\mathrm{cm})\end{array}$ & ${ }^{39} \mathrm{Ar} /{ }^{36} \mathrm{Ar}$ & ${ }^{40} \mathrm{Ar} /{ }^{36} \mathrm{Ar}$ & $\begin{array}{l}\text { Rad. }{ }^{40} \mathrm{Ar} \\
(\%)\end{array}$ & $\begin{array}{l}\text { Age } \pm 1 \sigma \\
(\mathrm{Ma})\end{array}$ \\
\hline \multicolumn{5}{|l|}{$112-687 \mathrm{~A}-6 \mathrm{H}-4,16-18$} \\
\hline Step 1 & 11.357 & 297.50 & 0.7 & $1.05 \pm 0.33$ \\
\hline Step 2 & 630.73 & 440.48 & $32: 9$ & $1.37 \pm 0.09$ \\
\hline Step 3 & 266.32 & 362.94 & 18.6 & $1.51 \pm 0.08$ \\
\hline Step 4 & 84.562 & 310.05 & 4.7 & $1.02 \pm 0.17$ \\
\hline \multicolumn{4}{|c|}{ Total fusion age (all steps combined) } & 1.30 \\
\hline \multicolumn{4}{|c|}{ Plateau age (steps 3 and 4 ) } & $1.42 \pm 0.06$ \\
\hline \multicolumn{4}{|c|}{ Isochron age (all steps) } & $1.41 \pm 0.06$ \\
\hline \multicolumn{3}{|c|}{${ }^{40} \mathrm{Ar}{ }^{39} \mathrm{Ar}$ intercept } & & $293.10 \pm 2.9$ \\
\hline \multicolumn{5}{|c|}{$\begin{array}{l}\text { Analyses performed by R. A. Duncan, K/Ar facility at the College of Oceanography, Oregor } \\
\text { State University. }\end{array}$} \\
\hline
\end{tabular}

Above $50 \mathrm{~m}$, benthic foraminifers were absent (Shipboard Scientifc Party, 1988b). Further radiometric dating should be attempted to coordinate the isolated interval of oxygen-isotope variations with both organic carbon and grain-size distribution patterns. In the following discussion, we present one such attempt to correlate isotope data, grain size, and organiccarbon distribution, but we are aware that the resulting stratigraphy is tenuous. Information about sedimentary cycles was sought by determining the $<32-\mu \mathrm{m}$ grain-size fraction and organic-carbon content, both of which exhibit recognizable cycles (Figs. 5B and 5C). Changes in the weight-percent of the size class $<32 \mu \mathrm{m}$ generally agree with lithological changes indicated in the core descriptions. Laminated sections correlate with intervals having an increased proportion of the $<32-\mu \mathrm{m}$ fraction, while bioturbated portions correspond to

\section{Depth $(m)$ in Standard}

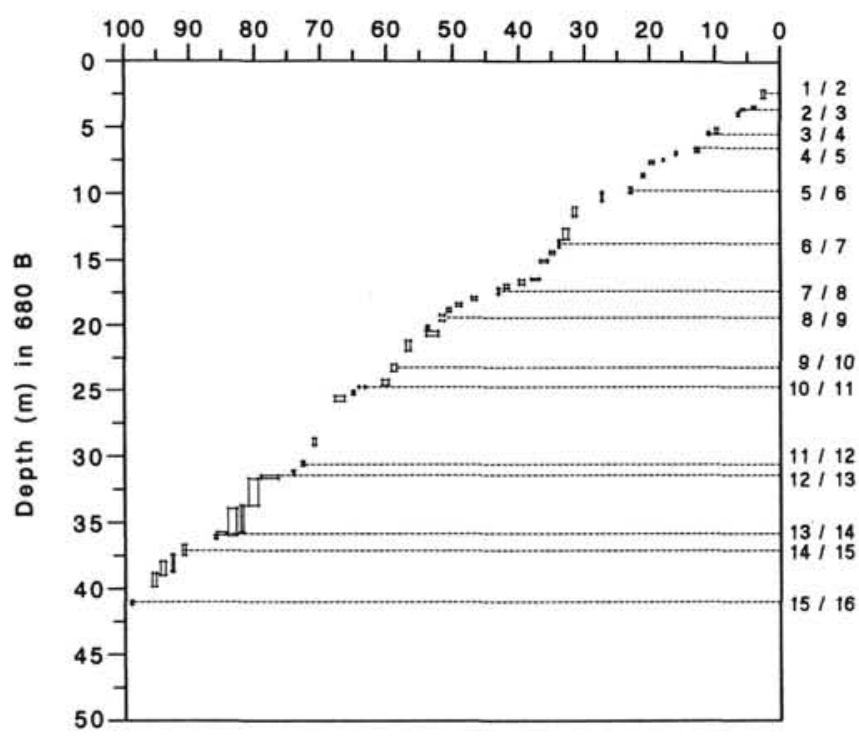

Figure 4. Graphic correlation diagram of Hole $680 \mathrm{~B}$ vs. the standard reference section of Prell et al. (1986). segments having less of this fraction. Between 57 and $114 \mathrm{~m}$, intervals characterized by light isotopic values exhibit an excellent correlation with intervals of high organic-carbon content and high levels of the percentage of $<32-\mu \mathrm{m}$ fraction.

The organic-carbon content at Hole $686 \mathrm{~B}$ varies between extremes of $6 \mathrm{wt} \%$ organic carbon and $<0.5 \mathrm{wt} \%$ organic carbon, with a mean value of about $1.5 \mathrm{wt} \%$ organic carbon (Fig. 5B). In general, higher organic-carbon values are found in laminated sections and vice versa (see visual core descriptions, Shipboard Scientific Party, 1988b). The maxima themselves are sharply subdivided by short intervals of low organic-carbon contents. Sections having high organic-carbon content exhibit low isotopic values and vice versa (Figs. 6 and 7). Below $120 \mathrm{~m}$, the distribution of organic carbon shows two well-developed maxima bracket by one minimum, as observed in the oxygen-isotope distribution (Fig. 6). Specifically in this interval, but generally throughout the core, the organiccarbon maxima coincide with interglacial oxygen-isotope stages, while the minima correspond to glacial stages (Figs. $5 \mathrm{~A}, 5 \mathrm{~B}, 6$, and 7). Glacial to interglacial changes are also seen in the weight percent of the $<32-\mu \mathrm{m}$ fraction (Fig. 5C). The correlation between interglacial stages, as indicated by low $\delta^{18} \mathrm{O}$-values, and high values of both the $<32-\mu \mathrm{m}$ fraction and the weight percent of organic carbon was clearly observed in the interval between 57 and $85 \mathrm{~m}$ (Fig. 5). Isotope Stages 1 to 15 could be tentatively identified from the organic-carbon contents and the grain-size distributions (Figs. 5 and 7). Using the graphic method of Prell et al. (1986), a correlation was established between the stage boundaries and the standard reference section (Fig. 8, Table 3). High rates of sedimentation, as seen below $120 \mathrm{~m}$, are also evident above this level if we assume that the maxima and minima generally reflect a 100 k.y. cyclicity and that between 105 and $120 \mathrm{~m}$ a major hiatus exists (Table 3 ).

\section{Sedimentation Rates}

The mean sedimentation rate at Hole $680 \mathrm{~B}$ over the undisturbed core interval between the sediment/water interface and $41.0 \mathrm{~m}$ is $6.6 \mathrm{~cm} / \mathrm{k}$.y. However, a significant fine-scale structure is apparent in the sedimentation rates from one stage or substage to the next (Table 1), with several plausible devia- 


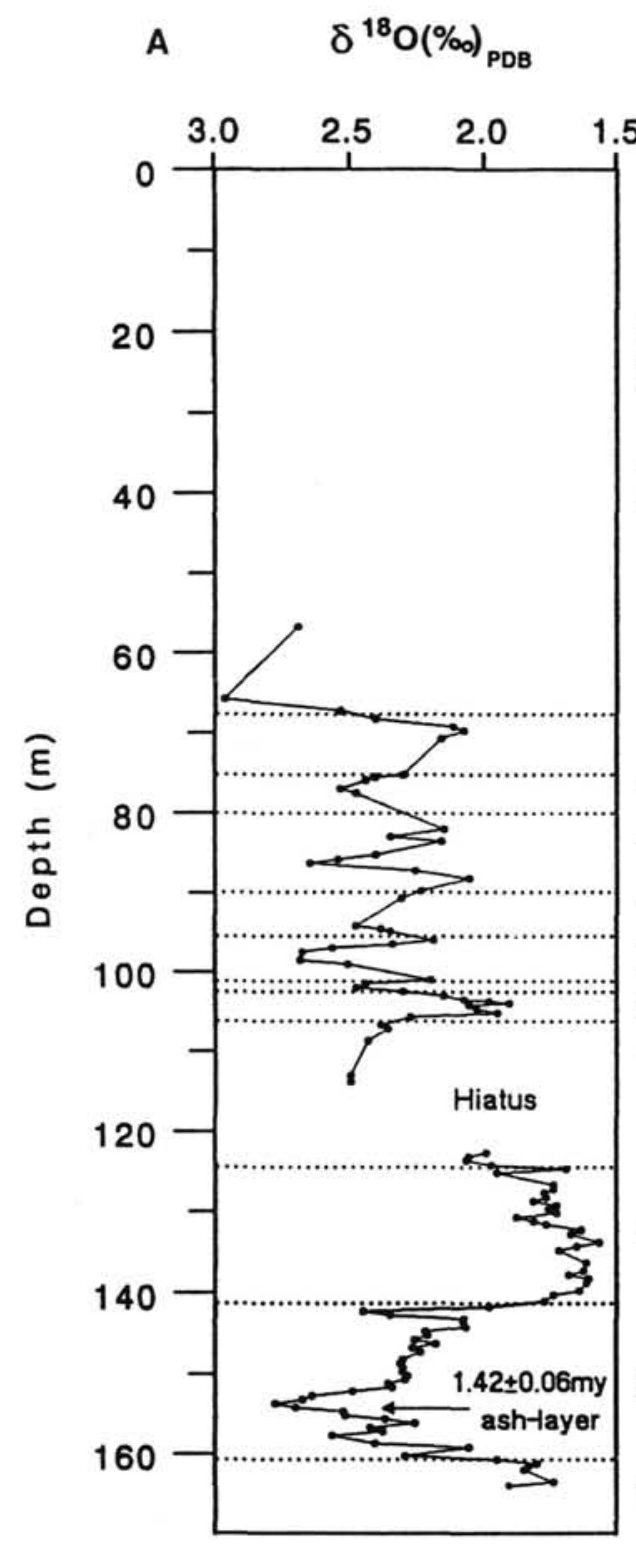

B weight-\% C-org

C weight.\% $<32 \mu \mathrm{m}$
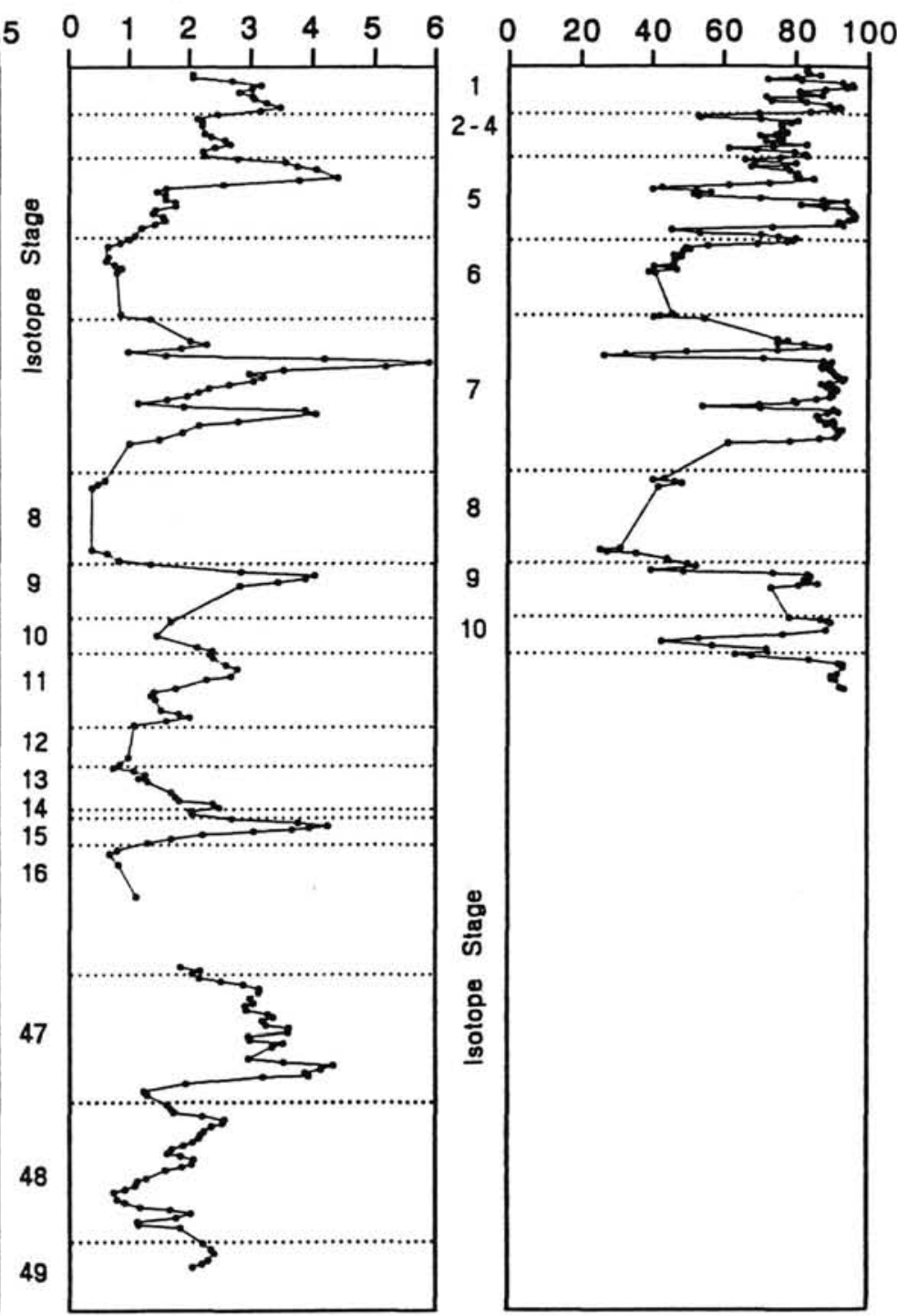

Figure 5. Hole 686B downhole variations. A. Oxygen-isotope composition of the benthic foraminifer Bolivina seminuda humilis; B. Organic carbon content. C. Grain-size distribution $(<32 \mu \mathrm{m})$; note that fine-grained intervals generally correspond to interglacial periods.

tions from this mean. First, the Holocene interval was rapidly sedimented (about $21 \mathrm{~cm} / \mathrm{k} . \mathrm{y}$.). This is largely due to the lack of compaction. The sedimentation rate during Stage 2 is probably also partly affected by low compaction. Second, a decrease in the sedimentation rate relative to the mean occurs during Stages 8,12 , and 14 . In general, this decrease is accompanied by low organic-carbon contents and coarse sediment textures, probably indicating reworking, winnowing, and incipient erosion of the sediment record during low stands of sea level. Therefore, it is an "apparent" decrease, rather than a lack of sediment flux. Third, sedimentation rates with values near that of the mean are observed during Stages 3 to $7,10,11,13$, and 15 . We consider this to be the least disturbed section and representative of material sedimented from a coastal upwelling zone.

The mean sedimentation rate over the late Pleistocene core interval at Site 686 is $17.1 \mathrm{~cm} / \mathrm{k} . \mathrm{y}$. above the hiatus (isotope Stages 1 through 15 ) and $100 \mathrm{~cm} / \mathrm{k}$.y. below this level. As we observed at Site 680 , the sedimentation rate was about three times higher than the mean during Stage 1 (i.e., $52 \mathrm{~cm} / \mathrm{k}$.y.). In this case, we hesitate to attribute the high rate entirely to lack of compaction as not only laminated, but also bioturbated and coarse-grained sediments are plentiful. Rather, we prefer to invoke a higher Holocene sediment flux. Because of the tentative assignment of chronostratigraphic boundaries at this site, it is obviously not reasonable to speculate on the causes of any fine-structure in the rates between stages and substages.

\section{Depositional Environment}

Above oxygen-isotope Stage 15 a clear relationship is observed between variations in $\delta^{18} \mathrm{O}$ and lithology at both holes (Figs. 2A and 5A). Laminated diatomacous mud is preferentially preserved during warm intervals, documented by light $\delta^{18} \mathrm{O}$ values. On the other hand, burrowed sands and silty muds were deposited during cold times (heavy $\delta^{18} \mathrm{O}$ 
Table 3. Depths and ages of stage boundaries as well as sedimentation rates of Hole 686B.

\begin{tabular}{|c|c|c|c|}
\hline Stage & $\begin{array}{l}\text { Stage-boundary } \\
\text { (mbsf) }\end{array}$ & $\operatorname{Age}^{a}$ (k.y.) & $\begin{array}{c}\text { Sedimentation } \\
\text { rate } \\
(\mathrm{cm} / \mathrm{k} . \mathrm{y} .)\end{array}$ \\
\hline & 0 & 0 & \\
\hline 1 & 6.3 & 12.05 & 52.3 \\
\hline 2 & & & 22.4 \\
\hline 3 & 9.0 & 24.11 & 6.3 \\
\hline 4 & 11.2 & 58.96 & 6.7 \\
\hline 5 & 12.2 & 73.91 & 20.6 \\
\hline 6 & 23.7 & 129.84 & 17.7 \\
\hline 7 & 34.3 & 189.61 & 38.3 \\
\hline 8 & 55.2 & 244.18 & 21.3 \\
\hline & 67.7 & 303.00 & \\
\hline 9 & 75.3 & 339.00 & 20.9 \\
\hline 10 & 80.0 & 362.00 & 20.7 \\
\hline 11 & 90.1 & 423.00 & 16.6 \\
\hline 12 & 95.5 & 478.00 & 9.9 \\
\hline 13 & 101.3 & 524.00 & 12.4 \\
\hline 14 & 102.5 & 565.00 & 3.0 \\
\hline 15 & 106.3 & 620.00 & 6.9 \\
\hline 47 & $\begin{array}{l}124.0 \\
141.5\end{array}$ & $\begin{array}{l}1370.00 \\
1401.00\end{array}$ & 56.5 \\
\hline 48 & 160.8 & 1415.00 & 137.5 \\
\hline
\end{tabular}

${ }^{a}$ Ages taken from Imbrie et al. (1984), Martinson et al. (1987), and Williams et al. (1988).

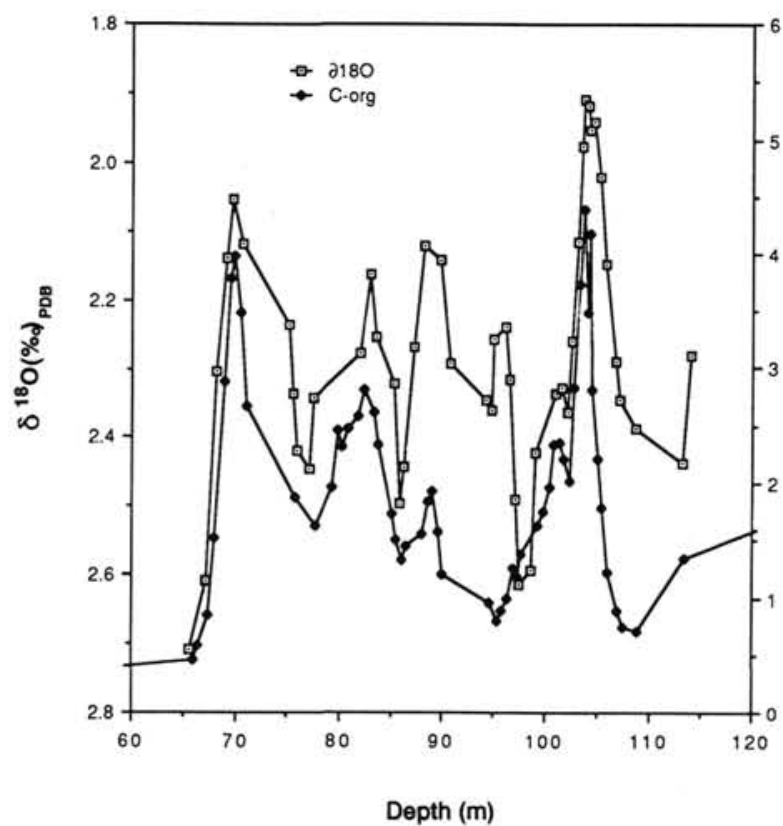

Figure 6. Comparison of Hole 686B downhole variations in oxygen isotope composition of the benthic foraminifer Bolivina seminuda humilis with organic carbon content at depth interval 122 to $171 \mathrm{~m}$.

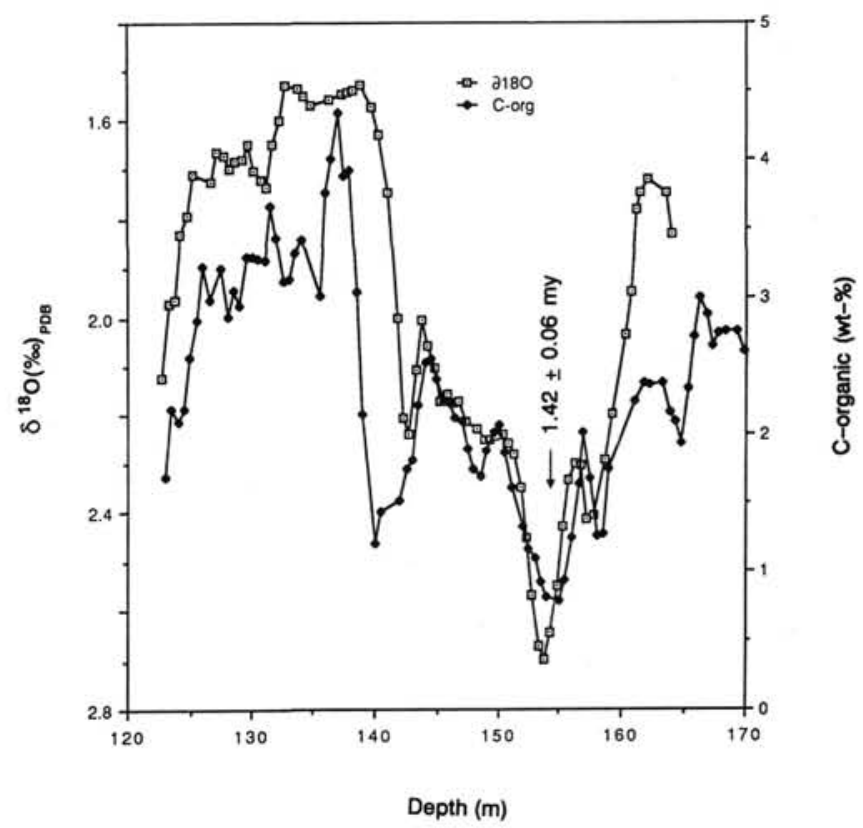

Figure 7. Comparison of Hole 686B downhole variations in oxygenisotope composition of the benthic foraminifer Bolivina seminuda humilis with organic-carbon content at depth interval 57 to $114 \mathrm{~m}$.

values), when either upwelling was weaker or preservation was poorer, than during interglacial times. In Hole $686 \mathrm{~B}$, the $\delta^{18} \mathrm{O}$ values over the interval between 57 and $114 \mathrm{~m}$ and the interval below $122 \mathrm{~m}$ also correlate well with lithology: low $\delta^{18} \mathrm{O}$ values correspond to laminated sediments and vice versa. At Site 686 , laminated diatomaceous mud was similarly deposited during interglacial times, while burrowed sands and silty muds were sedimented during glacial intervals. Changes between bioturbated and laminated sections are more clearly distinguished in Hole 686A than in Hole 686B (Shipboard Scientific Party, 1988b). Generally, however, sediments at

$$
\text { Depth }(\mathrm{m}) \text { in Standard }
$$

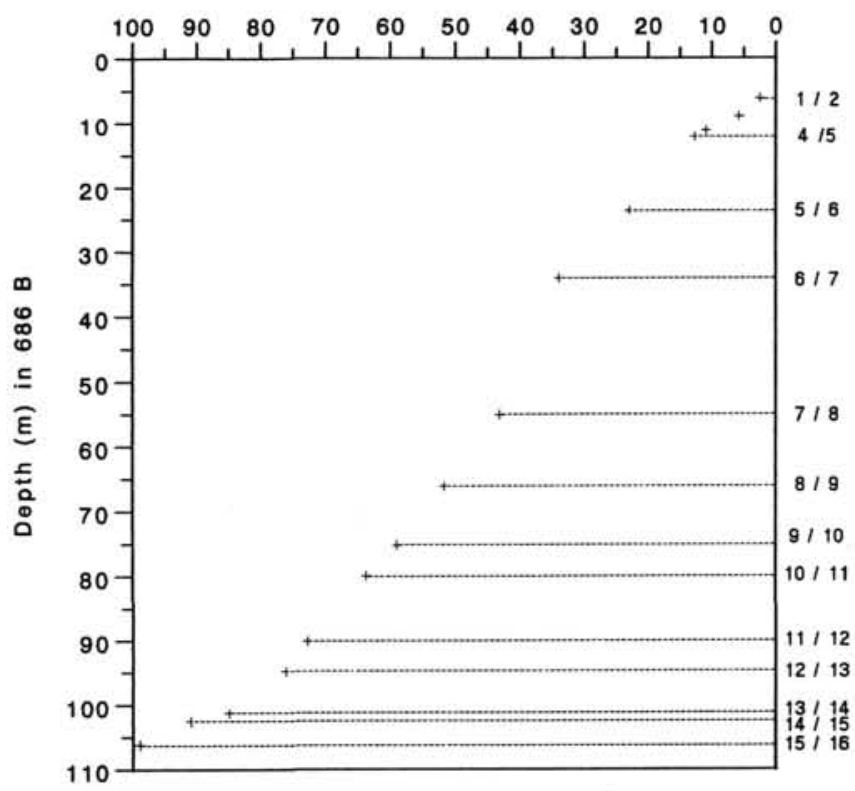

Figure 8. Diagram of graphic correlation of Hole 686B vs. the standard reference section of Prell et al. (1986). 
Hole $686 \mathrm{~B}$ are coarser than at Hole $680 \mathrm{~B}$ and have significantly less organic matter. Presumably, lower values of organic carbon in the sediment are related to higher oxygen levels in the bottom water and/or dilution by terrigenous components.

The flux of terrigenous detritus is primarily determined by two factors: (1) the greater proximity to land during glacial intervals due to lowered sea levels may facilitate increased terrigenous flux and result in increased bottom current activity, thereby causing reworking and winnowing of fine-grained sediment components, and (2) tectonic processes and subsidence may be invoked to account for the deposition of coarser sediment.

Today, both drill sites are located near upwelling cells having a high supply of organic matter and low oxygen conditions in the bottom water. During lowered sea levels in glacial times, the sites may have shifted landward or to the north or south of these upwelling centers. At this shallower position, production of organic matter in the euphotic zone should have been lower, permitting higher oxygen contents in the bottom water and leading to increased bioturbation by bottom fauna and poorer preservation of organic carbon.

\section{ACKNOWLEDGMENTS}

We thank H. Erlenkeuser and H. Cordt for the isotope measurements, and R. A. Duncan for the K/Ar analyses. This research was supported by the German Research Foundation and by the U.S. National Science Foundation. We thank Mona Botros for a critical review.

\section{REFERENCES}

Imbrie, J., Hays, J., Martinson, D., McIntyre, A., Mix, A., Morley, J., Pisias, N., Prell, W., and Shackleton, N., 1984. The orbital theory of Pleistocene climate: support from a revised chronology of the marine $\delta^{18} \mathrm{O}$ record. In Berger, A., Imbrie, J., Hays, J., Kukla, G., and Saltzman, B. (Eds.), Milankovitch and Climate. Part 1: Dordrecht (Riedel), 269-305.

Martinson, D., Pisias, N., Hays, J., Imbrie, J., Moore, T., and Shackleton, N., 1987. Age dating and the orbital theory of the Ice Ages: development of a high resolution 0 to 300,000 -year chronology. Quat. Res., 27:1-29.

Matoba, Y., and Yamaguchi, A., 1982. Late Pliocene-to-Holocene benthic foraminifers of the Guaymas Basin, Gulf of California: Sites 477 through 481. In Curray, J. R., Moore, D. G., et al., Init. Repts. DSDP, 64: Washington (U.S. Govt. Printing Office), $1027-$ 1056.

Prell, W., Imbrie, J., Martinson, D., Morley, J., Pisias, N., Shackleton, N., and Streeter, H., 1986. Graphic correlation of oxygen isotope stratigraphy: application to the late Quaternary. Paleoceanography, 1:137-162.
Reimers, C. E., and Suess, E., 1983. Spatial and temporal patterns of organic matter accumulation on the Peru continental margin. In Suess, E., and Thiede, J. (Eds.), Coastal Upwelling Part B: Sedimentary Records of Ancient Coastal Upwelling: New York (Plenum Press), 311-345.

Resig, J. M., 1981. Biogeography of benthic foraminifera of the northern Nazca plate and adjacent continental margin. Geol. Soc. Am. Mem., 154:619-665.

Ruddiman, W. F., Raymo, M., and McIntyre, A., 1986. Matuyama 41,000-year cycles: North Atlantic Ocean and Northern Hemisphere ice sheets. Earth Planet. Sci. Lett., 80:117-129.

Shipboard Scientific Party, 1988a. Site 680. In Suess, E., von Huene, R., et al., 1988. Proc. ODP, Init. Repts., 112: College Station, TX (Ocean Drilling Program), 249-303.

1988b. Site 686. In Suess, E., von Huene, R., et al., 1988. Proc. ODP, Init. Repts., 112: College Station, TX (Ocean Drilling Program), 705-802.

1988c. Site 687. In Suess, E., von Huene, R., et al., 1988. Proc. ODP, Init. Repts., 112: College Station, TX (Ocean Drilling Program), 803-877.

Smith, P. B., 1963. Quantitative and qualitative analysis of the family Bolivinidae. U.S. Geol. Surv. Prof. Pap., 429(A):1-45.

Suess, E., and von Huene, R., et al., 1988a. Ocean Drilling Program Leg 112; Peru Continental Margin: Part 2-Sedimentary history and diagenesis in a coastal upwelling environment. Geology, 16:939-943.

Suess, E., von Huene, R., et al., 1988b. Proc. ODP, Init. Repts., 112: College Station, TX (Ocean Drilling Program).

Suess, E., and Thiede, J., 1983. Responses of the sedimentary regime to coastal upwelling. In Suess, E., and Thiede, J. (Eds.), Coastal Upwelling: Its Sediment Record, Part A: New York (Plenum Press).

Thornburg, T. M., 1985. Seismic stratigraphy of Peru forearc basins. In Hussong, D. M., Dang, S. P., Kulm, L. D., Couch, R. W., and Hilde, T.W.C. (Eds.), Atlas of the Ocean Margin Program, Peru Continental Margin, Region VI: Woods Hole (Mar. Sci. Int.), 16.

Uchio, T., 1960. Ecology of living benthonic foraminifera from the San Diego, California, Area. Cush. Found. Spec. Publ., 5:1-72.

Wefer, G., Dunbar, R. B., and Suess, E., 1983. Stable isotopes of foraminifers off Peru recording high fertility and changes in upwelling history. In Thiede, J., and Suess, E. (Eds.), Coastal Upwelling: Its Sediment Record, Part B: New York (Plenum Press), 295-308.

Weliky, K., Suess, E., and Ungerer, C. A., 1983. Problems with accurate carbon measurements in marine sediments and particulate matter in seawater: A new approach. Limnol. Oceanogr., 28(6): $1252-1259$.

Williams, D. F., Thunell, R. C., Tappa, E., Rio, D., and Raffi, I., 1988. Chronology of the Pleistocene oxygen isotope record: 0-1.88 m.y. B.P. Palaeogeogr., Palaeoclimatol., Palaeoecol., 64:221-240.

Date of initial receipt: 12 December 1988

Date of acceptance: 21 June 1989

Ms 112B-164 
APPENDIX

Table 1. Grain-size distribution of sediments from Hole $680 \mathrm{~B}$.

\begin{tabular}{|c|c|c|}
\hline $\begin{array}{l}\text { Core, section, } \\
\text { interval }(\mathrm{cm})\end{array}$ & $\begin{array}{l}\text { Depth } \\
\text { (mbsf) }\end{array}$ & $\begin{array}{c}\text { Fraction } \\
<63 \mu \mathrm{m} \\
(w t \%)\end{array}$ \\
\hline $112-680 \mathrm{~B}-1 \mathrm{H}-1,3-4$ & 0.03 & 98.67 \\
\hline $1 \mathrm{H}-1,15-19$ & 0.18 & 98.30 \\
\hline $1 \mathrm{H}-1,23-27$ & 0.23 & 98.08 \\
\hline $1 \mathrm{H}-1,35-39$ & 0.35 & 96.58 \\
\hline $1 \mathrm{H}-1,40-41$ & 0.40 & 98.64 \\
\hline $1 \mathrm{H}-1,48-52$ & 0.48 & 95.76 \\
\hline $1 \mathrm{H}-1,52-53$ & 0.52 & 96.18 \\
\hline $1 \mathrm{H}-1,65-66$ & 0.65 & 93.67 \\
\hline $1 \mathrm{H}-1,73-77$ & 0.73 & 94.85 \\
\hline $1 \mathrm{H}-1,87-88$ & 0.87 & 98.16 \\
\hline $1 \mathrm{H}-1,112-113$ & 1.12 & 96.77 \\
\hline $1 \mathrm{H}-1,123-125$ & 1.23 & 97.78 \\
\hline $1 \mathrm{H}-1,131-132$ & 1.31 & 92.71 \\
\hline $1 \mathrm{H}-1,146-150$ & 1.46 & 96.67 \\
\hline $1 \mathrm{H}-2,4-6$ & 1.54 & 97.29 \\
\hline $1 \mathrm{H}-2,14-16$ & 1.64 & 89.39 \\
\hline $1 \mathrm{H}-2,23-27$ & 1.73 & 97.17 \\
\hline $1 \mathrm{H}-2,29-31$ & 1.79 & 93.44 \\
\hline $1 \mathrm{H}-2,41-43$ & 1.91 & 96.11 \\
\hline $1 \mathrm{H}-2,48-52$ & 1.98 & 96.50 \\
\hline $1 \mathrm{H}-2,54-56$ & 2.04 & 91.26 \\
\hline $1 \mathrm{H}-2,73-77$ & 2.23 & 69.81 \\
\hline $1 \mathrm{H}-2,79-81$ & 2.29 & 88.88 \\
\hline $1 \mathrm{H}-2,91-93$ & 2.41 & 65.60 \\
\hline $1 \mathrm{H}-2,98-102$ & 2.48 & 93.63 \\
\hline $1 \mathrm{H}-2,113-115$ & 2.63 & 96.21 \\
\hline $1 \mathrm{H}-2,123-127$ & 2.73 & 88.44 \\
\hline $1 \mathrm{H}-2,134-136$ & 2.84 & 91.60 \\
\hline $1 \mathrm{H}-3,23-27$ & 3.23 & 62.78 \\
\hline $1 \mathrm{H}-3,39-40$ & 3.39 & 63.90 \\
\hline $1 \mathrm{H}-3,48-52$ & 3.48 & 75.26 \\
\hline $1 \mathrm{H}-3,73-77$ & 3.73 & 95.43 \\
\hline $1 \mathrm{H}-3,83-84$ & 3.83 & 96.49 \\
\hline $1 \mathrm{H}-3,98-102$ & 3.98 & 97.86 \\
\hline $1 \mathrm{H}-3,109-110$ & 4.09 & 98.29 \\
\hline $1 \mathrm{H}-3,123-127$ & 4.23 & 95.81 \\
\hline $1 \mathrm{H}-3,146-150$ & 4.46 & 97.59 \\
\hline $1 \mathrm{H}-4,23-27$ & 4.73 & 97.61 \\
\hline $1 \mathrm{H}-4,43-44$ & 4.93 & 96.02 \\
\hline $1 \mathrm{H}-4,48-52$ & 4.98 & 97.45 \\
\hline $1 \mathrm{H}-4,73-77$ & 5.23 & 98.00 \\
\hline $2 \mathrm{H}-1,23-27$ & 5.73 & 97.91 \\
\hline $2 \mathrm{H}-1,40-41$ & 5.90 & 98.28 \\
\hline $2 \mathrm{H}-1,48-50$ & 5.98 & 98.95 \\
\hline $2 \mathrm{H}-1,73-77$ & 6.23 & 98.15 \\
\hline $2 \mathrm{H}-1,87-88$ & 6.37 & 98.03 \\
\hline $2 \mathrm{H}-1,98-102$ & 6.48 & 97.77 \\
\hline $2 \mathrm{H}-1,123-127$ & 6.73 & 95.79 \\
\hline $2 \mathrm{H}-1,138-139$ & 6.88 & 97.08 \\
\hline $2 \mathrm{H}-1,146-150$ & 6.96 & 96.26 \\
\hline $2 \mathrm{H}-2,23-27$ & 7.23 & 96.24 \\
\hline $2 \mathrm{H}-2,40-41$ & 7.40 & 93.89 \\
\hline $2 \mathrm{H}-2,48-52$ & 7.48 & 98.35 \\
\hline $2 \mathrm{H}-2,73-77$ & 7.73 & 94.89 \\
\hline $2 \mathrm{H}-2,88-89$ & 7.88 & 94.71 \\
\hline $2 \mathrm{H}-2,98-102$ & 7.98 & 96.28 \\
\hline $2 \mathrm{H}-2,123-127$ & 8.23 & 93.50 \\
\hline $2 \mathrm{H}-2,135-136$ & 8.35 & 94.54 \\
\hline $2 \mathrm{H}-2,146-150$ & 8.46 & 90.44 \\
\hline $2 \mathrm{H}-3,23-27$ & 8.73 & 95.61 \\
\hline $2 \mathrm{H}-3,40-41$ & 8.90 & 95.71 \\
\hline $2 \mathrm{H}-3,48-52$ & 8.98 & 89.50 \\
\hline $2 \mathrm{H}-3,73-77$ & 9.23 & 94.36 \\
\hline $2 \mathrm{H}-3,88-89$ & 9.38 & 96.36 \\
\hline $2 \mathrm{H}-3,98-102$ & 9.48 & 95.88 \\
\hline $2 \mathrm{H}-3,123-127$ & 9.73 & 99.03 \\
\hline $2 \mathrm{H}-3,135-136$ & 9.85 & 98.61 \\
\hline $2 \mathrm{H}-3,146-150$ & 9.96 & 98.85 \\
\hline $2 \mathrm{H}-4,23-27$ & 10.23 & 98.53 \\
\hline $2 \mathrm{H}-4,48-52$ & 10.48 & 97.38 \\
\hline $2 \mathrm{H}-4,73-77$ & 10.73 & 79.92 \\
\hline $2 \mathrm{H}-4,98-102$ & 10.98 & 97.63 \\
\hline $2 \mathrm{H}-4,123-127$ & 11.23 & 93.17 \\
\hline
\end{tabular}

Table 1 (continued).

\begin{tabular}{|c|c|c|c|c|c|}
\hline $\begin{array}{l}\text { Core, section, } \\
\text { interval }(\mathrm{cm})\end{array}$ & $\begin{array}{l}\text { Depth } \\
\text { (mbsf) }\end{array}$ & $\begin{array}{c}\text { Fraction } \\
<63 \mu \mathrm{m} \\
(w \mathrm{t} \%)\end{array}$ & $\begin{array}{l}\text { Core, section, } \\
\text { interval }(\mathrm{cm})\end{array}$ & $\begin{array}{l}\text { Depth } \\
\text { (mbsf) }\end{array}$ & $\begin{array}{c}\text { Fraction } \\
<63 \mu \mathrm{m} \\
(w t \%)\end{array}$ \\
\hline $2 \mathrm{H}-4,146-150$ & 11.46 & 98.98 & $4 \mathrm{H}-4,73-77$ & 29.73 & 95.03 \\
\hline $2 \mathrm{H}-5,23-27$ & 11.73 & 99.15 & $4 \mathrm{H}-4,98-102$ & 29.98 & 82.51 \\
\hline $2 \mathrm{H}-5,48-52$ & 11.98 & 99.28 & $4 \mathrm{H}-4,123-127$ & 30.23 & 89.71 \\
\hline $2 \mathrm{H}-5,73-77$ & 12.23 & 99.04 & $4 \mathrm{H}-4,146-150$ & 30.46 & 86.42 \\
\hline $2 \mathrm{H}-5,98-102$ & 12.48 & 99.21 & $4 \mathrm{H}-5,23-27$ & 30.73 & 98.42 \\
\hline $2 \mathrm{H}-5,123-127$ & 12.73 & 98.96 & $4 \mathrm{H}-5,48-52$ & 30.98 & 47.68 \\
\hline $2 \mathrm{H}-5,146-150$ & 12.96 & 98.97 & $4 \mathrm{H}-5,73-77$ & 31.23 & 52.43 \\
\hline $2 \mathrm{H}-6,23-27$ & 13.23 & 98.65 & $4 \mathrm{H}-5,98-102$ & 31.48 & 65.96 \\
\hline $2 \mathrm{H}-6,48-52$ & 13.48 & 98.11 & $4 \mathrm{H}-5,123-127$ & 31.73 & 97.28 \\
\hline $2 \mathrm{H}-6,73-77$ & 13.73 & 98.84 & $4 \mathrm{H}-5,146-150$ & 31.96 & 94.33 \\
\hline $2 \mathrm{H}-6,123-127$ & 14.23 & 96.03 & $4 \mathrm{H}-6,23-27$ & 32.23 & 98.10 \\
\hline $2 \mathrm{H}-6,146-150$ & 14.46 & 98.41 & $4 \mathrm{H}-6,48-52$ & 32.48 & 95.07 \\
\hline $2 \mathrm{H}-7,23-27$ & 14.73 & 93.08 & $4 \mathrm{H}-6,73-77$ & 32.73 & 32.25 \\
\hline $2 \mathrm{H}-7,48-52$ & 14.98 & 99.14 & $4 \mathrm{H}-6,98-102$ & 32.98 & 71.54 \\
\hline $2 \mathrm{H}-7,66-70$ & 15.16 & 95.74 & $4 \mathrm{H}-6,123-127$ & 33.23 & 48.68 \\
\hline $3 \mathrm{H}-1,23-27$ & 15.23 & 98.15 & $4 \mathrm{H}-6,146-150$ & 33.46 & 47.04 \\
\hline $3 \mathrm{H}-1,48-52$ & 15.48 & 97.44 & $4 \mathrm{H}-7,23-27$ & 33.73 & 53.05 \\
\hline $3 \mathrm{H}-1,73-77$ & 15.73 & 98.40 & $4 \mathrm{H}-7,48-52$ & 33.98 & 69.31 \\
\hline $3 \mathrm{H}-1,98-102$ & 15.98 & 71.38 & $5 \mathrm{H}-1,23-27$ & 34.23 & 98.78 \\
\hline $3 \mathrm{H}-1,123-127$ & 16.23 & 96.36 & $5 \mathrm{H}-1,48-50$ & 34.48 & 95.50 \\
\hline $3 \mathrm{H}-1,146-150$ & 16.46 & 95.58 & $5 \mathrm{H}-1,73-77$ & 34.73 & 57.59 \\
\hline $3 \mathrm{H}-2,23-27$ & 16.73 & 95.06 & $5 \mathrm{H}-1,98-102$ & 34.98 & 79.89 \\
\hline $3 \mathrm{H}-2,48-52$ & 16.98 & 95.39 & $5 \mathrm{H}-1,123-127$ & 35.23 & 95.26 \\
\hline $3 \mathrm{H}-2,73-77$ & 17.23 & 97.34 & $5 \mathrm{H}-1,146-150$ & 35.46 & 33.34 \\
\hline $3 \mathrm{H}-2,98-102$ & 17.48 & 97.88 & $5 \mathrm{H}-2,23-27$ & 35.73 & 98.19 \\
\hline $3 \mathrm{H}-2,123-127$ & 17.73 & 94.76 & $5 \mathrm{H}-2,48-52$ & 35.98 & 95.63 \\
\hline $3 \mathrm{H}-2,146-150$ & 17.96 & 92.06 & $5 \mathrm{H}-2,73-77$ & 36.23 & 97.45 \\
\hline $3 \mathrm{H}-3,23-27$ & 18.23 & 96.06 & $5 \mathrm{H}-2,123-127$ & 36.73 & 78.46 \\
\hline $3 \mathrm{H}-3,48-52$ & 18.48 & 95.43 & $5 \mathrm{H}-2,146-150$ & 36.96 & 97.35 \\
\hline $3 \mathrm{H}-3,73-77$ & 18.73 & 97.31 & $5 \mathrm{H}-3,23-27$ & 37.23 & 98.62 \\
\hline $3 \mathrm{H}-3,98-102$ & 18.98 & 97.79 & $5 \mathrm{H}-3,48-52$ & 37.48 & 96.91 \\
\hline $3 \mathrm{H}-3,110-114$ & 19.10 & 95.55 & $5 \mathrm{H}-3,73-77$ & 37.73 & 98.81 \\
\hline $3 \mathrm{H}-4,23-27$ & 19.73 & 98.29 & $5 \mathrm{H}-3,98-102$ & 37.98 & 96.70 \\
\hline $3 \mathrm{H}-4,48-52$ & 19.98 & 86.94 & $5 \mathrm{H}-3,123-127$ & 38.23 & 98.97 \\
\hline $3 \mathrm{H}-4,73-77$ & 20.23 & 97.81 & $5 \mathrm{H}-4,23-27$ & 38.73 & 97.67 \\
\hline $3 \mathrm{H}-4,98-102$ & 20.48 & 96.48 & $5 \mathrm{H}-4,48-52$ & 38.98 & 98.28 \\
\hline $3 \mathrm{H}-4,123-127$ & 20.73 & 97.81 & $5 \mathrm{H}-4,73-77$ & 39.23 & 98.86 \\
\hline $3 \mathrm{H}-4,146-150$ & 20.96 & 83.55 & $5 \mathrm{H}-4,98-102$ & 39.48 & 99.05 \\
\hline $3 \mathrm{H}-5,23-27$ & 21.23 & 92.83 & $5 \mathrm{H}-4,123-127$ & 39.73 & 99.04 \\
\hline $3 \mathrm{H}-5,48-52$ & 21.48 & 93.05 & $5 \mathrm{H}-4,146-150$ & 39.96 & 96.32 \\
\hline $3 \mathrm{H}-5,73-77$ & 21.73 & 97.61 & $5 \mathrm{H}-5,23-27$ & 40.23 & 88.63 \\
\hline $3 \mathrm{H}-5,98-102$ & 21.98 & 93.66 & $5 \mathrm{H}-5,48-52$ & 40.48 & 85.93 \\
\hline $3 \mathrm{H}-5,123-127$ & 22.23 & 95.36 & $5 \mathrm{H}-5,73-77$ & 40.73 & 82.95 \\
\hline $3 \mathrm{H}-5,146-150$ & 22.46 & 87.75 & $5 \mathrm{H}-5,98-102$ & 40.98 & 74.05 \\
\hline $3 \mathrm{H}-6,23-27$ & 22.73 & 95.44 & $5 \mathrm{H}-5,123-127$ & 41.23 & 73.92 \\
\hline $3 \mathrm{H}-6,48-52$ & 22.98 & 98.53 & $5 \mathrm{H}-5,146-150$ & 41.46 & 68.07 \\
\hline $3 \mathrm{H}-6,73-77$ & 23.23 & 97.40 & $5 \mathrm{H}-6,23-27$ & 41.73 & 83.13 \\
\hline $3 \mathrm{H}-6,98-102$ & 23.48 & 98.35 & $5 \mathrm{H}-6,48-52$ & 41.98 & 88.53 \\
\hline $3 \mathrm{H}-6,123-127$ & 23.73 & 98.61 & $5 \mathrm{H}-6,73-77$ & 42.23 & 79.87 \\
\hline $3 \mathrm{H}-6,146-150$ & 23.96 & 99.02 & $5 \mathrm{H}-6,123-127$ & 42.73 & 80.44 \\
\hline $3 \mathrm{H}-7,23-27$ & 24.23 & 96.71 & $5 \mathrm{H}-6,146-150$ & 42.96 & 77.69 \\
\hline $3 \mathrm{H}-7,48-52$ & 24.48 & 35.59 & $5 \mathrm{H}-7,23-27$ & 43.23 & 64.57 \\
\hline
\end{tabular}

Table 2. Organic carbon content of sediments from Hole $680 \mathrm{~B}$.

\begin{tabular}{lcc}
\hline $\begin{array}{c}\text { Core, section, } \\
\text { interval (cm) }\end{array}$ & $\begin{array}{c}\text { Depth } \\
\text { (mbsf) }\end{array}$ & $\begin{array}{c}\mathrm{C}_{\text {org }} \\
\text { (wt\%) }\end{array}$ \\
\hline $112-680 \mathrm{~B}-1 \mathrm{H}-1,3-4$ & 0.03 & 10.60 \\
$1 \mathrm{H}-1,10-14$ & 0.10 & 11.36 \\
$1 \mathrm{H}-1,18-19$ & 0.18 & 10.80 \\
$1 \mathrm{H}-1,23-27$ & 0.23 & 12.20 \\
$1 \mathrm{H}-1,48-52$ & 0.48 & 12.37 \\
$1 \mathrm{H}-1,98-102$ & 0.98 & 10.89 \\
$1 \mathrm{H}-1,112-113$ & 1.12 & 10.50 \\
$1 \mathrm{H}-1,123-125$ & 1.23 & 11.40 \\
$1 \mathrm{H}-1,146-150$ & 1.46 & 10.14 \\
$1 \mathrm{H}-2,4-6$ & 1.54 & 10.44 \\
$1 \mathrm{H}-2,48-52$ & 1.98 & 9.47 \\
$1 \mathrm{H}-2,98-102$ & 2.48 & 7.13
\end{tabular}


Table 2 (continued).

\begin{tabular}{|c|c|c|}
\hline $\begin{array}{l}\text { Core, section, } \\
\text { interval }(\mathrm{cm})\end{array}$ & $\begin{array}{l}\text { Depth } \\
\text { (mbsf) }\end{array}$ & $\begin{array}{l}\mathrm{C}_{\text {org }} \\
\text { (wt\%) }\end{array}$ \\
\hline $1 \mathrm{H}-3,12-13$ & 3.12 & 0.60 \\
\hline $1 \mathrm{H}-3,23-27$ & 3.27 & 2.58 \\
\hline $1 \mathrm{H}-3,39-40$ & 3.39 & 1.65 \\
\hline $1 \mathrm{H}-3,48-52$ & 3.48 & 1.47 \\
\hline $1 \mathrm{H}-3,66-67$ & 3.66 & 3.50 \\
\hline $1 \mathrm{H}-3,73-77$ & 3.73 & 5.12 \\
\hline $1 \mathrm{H}-3,83-84$ & 3.83 & 4.23 \\
\hline $1 \mathrm{H}-3,98-102$ & 3.98 & 4.51 \\
\hline $1 \mathrm{H}-3,109-110$ & 4.09 & 4.28 \\
\hline $1 \mathrm{H}-3,123-127$ & 4.23 & 5.17 \\
\hline $1 \mathrm{H}-3,131-132$ & 4.31 & 4.20 \\
\hline $1 \mathrm{H}-3,146-150$ & 4.46 & 5.60 \\
\hline $1 \mathrm{H}-4,2-4$ & 4.52 & 5.81 \\
\hline $1 \mathrm{H}-4,23-27$ & 4.73 & 4.77 \\
\hline $1 \mathrm{H}-4,43-44$ & 4.93 & 5.54 \\
\hline $1 \mathrm{H}-4,48-52$ & 4.98 & 4.76 \\
\hline $1 \mathrm{H}-4,62-63$ & 5.12 & 5.96 \\
\hline $2 \mathrm{H}-1,23-27$ & 5.73 & 4.99 \\
\hline $2 \mathrm{H}-1,27-29$ & 5.77 & 4.48 \\
\hline $2 \mathrm{H}-1,40-41$ & 5.90 & 5.75 \\
\hline $2 \mathrm{H}-1,48-50$ & 5.98 & 5.33 \\
\hline $2 \mathrm{H}-1,52-54$ & 6.02 & 5.21 \\
\hline $2 \mathrm{H}-1,61-62$ & 6.11 & 5.61 \\
\hline $2 \mathrm{H}-1,73-77$ & 6.23 & 6.05 \\
\hline $2 \mathrm{H}-1,77-79$ & 6.27 & 5.55 \\
\hline $2 \mathrm{H}-1,87-88$ & 6.37 & 5.38 \\
\hline $2 \mathrm{H}-1,92-94$ & 6.42 & 6.43 \\
\hline $2 \mathrm{H}-1,98-102$ & 6.48 & 5.54 \\
\hline $2 \mathrm{H}-1,107-109$ & 6.57 & 7.03 \\
\hline $2 \mathrm{H}-1,111-112$ & 6.61 & 5.41 \\
\hline $2 \mathrm{H}-1,131-133$ & 6.81 & 6.07 \\
\hline $2 \mathrm{H}-1,142-144$ & 6.92 & 6.32 \\
\hline $2 \mathrm{H}-1,146-150$ & 6.96 & 7.02 \\
\hline $2 \mathrm{H}-2,10-11$ & 7.10 & 8.27 \\
\hline $2 \mathrm{H}-2,36-38$ & 7.36 & 7.19 \\
\hline $2 \mathrm{H}-2,48-52$ & 7.48 & 6.63 \\
\hline $2 \mathrm{H}-2,61-62$ & 7.61 & 3.76 \\
\hline $2 \mathrm{H}-2,93-95$ & 7.93 & 8.59 \\
\hline $2 \mathrm{H}-2,98-102$ & 7.98 & 9.06 \\
\hline $2 \mathrm{H}-2,104-106$ & 8.04 & 6.49 \\
\hline $2 \mathrm{H}-2,109-110$ & 8.09 & 5.36 \\
\hline $2 \mathrm{H}-2,119-121$ & 8.19 & 6.75 \\
\hline $2 \mathrm{H}-2,144-146$ & 8.44 & 5.84 \\
\hline $2 \mathrm{H}-3,146-150$ & 8.46 & 5.83 \\
\hline $2 \mathrm{H}-3,7-9$ & 8.57 & 6.30 \\
\hline $2 \mathrm{H}-3,10-11$ & 8.60 & 4.97 \\
\hline $2 \mathrm{H}-3,15-17$ & 8.65 & 5.74 \\
\hline $2 \mathrm{H}-3,47-49$ & 8.97 & 5.45 \\
\hline $2 \mathrm{H}-3,48-52$ & 8.98 & 0.27 \\
\hline $2 \mathrm{H}-3,61-62$ & 9.11 & 0.31 \\
\hline $2 \mathrm{H}-3,93-95$ & 9.43 & 5.79 \\
\hline $2 \mathrm{H}-3,98-102$ & 9.48 & 5.04 \\
\hline $2 \mathrm{H}-3,109-110$ & 9.59 & 5.54 \\
\hline $2 \mathrm{H}-3,146-150$ & 9.96 & 4.20 \\
\hline $2 \mathrm{H}-4,48-52$ & 10.48 & 3.21 \\
\hline $2 \mathrm{H}-4,68-70$ & 10.68 & 2.51 \\
\hline $2 \mathrm{H}-4,91-93$ & 10.91 & 1.13 \\
\hline $2 \mathrm{H}-4,98-102$ & 10.98 & 6.24 \\
\hline $2 \mathrm{H}-4,129-133$ & 11.29 & 8.35 \\
\hline $2 \mathrm{H}-4,146-150$ & 11.46 & 7.36 \\
\hline $2 \mathrm{H}-5,27-29$ & 11.77 & 5.90 \\
\hline $2 \mathrm{H}-5,48-52$ & 11.98 & 5.54 \\
\hline $2 \mathrm{H}-5,64-66$ & 12.14 & 5.80 \\
\hline $2 \mathrm{H}-5,73-77$ & 12.23 & 6.06 \\
\hline $2 \mathrm{H}-5,93-95$ & 12.43 & 4.73 \\
\hline $2 \mathrm{H}-5,98-102$ & 12.48 & 5.77 \\
\hline $2 \mathrm{H}-5,104-106$ & 12.54 & 6.10 \\
\hline $2 \mathrm{H}-5,123-127$ & 12.73 & 6.44 \\
\hline $2 \mathrm{H}-5,140-142$ & 12.90 & 5.54 \\
\hline $2 \mathrm{H}-5,146-150$ & 12.96 & 5.98 \\
\hline $2 \mathrm{H}-6,23-27$ & 13.23 & 6.60 \\
\hline $2 \mathrm{H}-6,48-52$ & 13.48 & 6.23 \\
\hline $2 \mathrm{H}-6,73-77$ & 13.73 & 6.32 \\
\hline $2 \mathrm{H}-6,123-127$ & 14.23 & 3.08 \\
\hline $2 \mathrm{H}-6,130-132$ & 14.30 & 3.64 \\
\hline $2 \mathrm{H}-6,146-150$ & 14.46 & 3.17 \\
\hline $2 \mathrm{H}-7,23-27$ & 14.73 & 4.29 \\
\hline $2 \mathrm{H}-7,39-41$ & 14.89 & 6.56 \\
\hline
\end{tabular}

Table 2 (continued).

\begin{tabular}{|c|c|c|c|c|c|}
\hline $\begin{array}{l}\text { Core, section, } \\
\text { interval }(\mathrm{cm})\end{array}$ & $\begin{array}{l}\text { Depth } \\
\text { (mbsf) }\end{array}$ & $\begin{array}{l}\mathrm{C}_{\mathrm{org}} \\
\text { (wt\%) }\end{array}$ & $\begin{array}{l}\text { Core, section, } \\
\text { interval }(\mathrm{cm})\end{array}$ & $\begin{array}{l}\text { Depth } \\
\text { (mbsf) }\end{array}$ & $\underset{\text { (wt\%) }}{\mathrm{C}_{\text {org }}}$ \\
\hline $2 \mathrm{H}-7,48-52$ & 14.98 & 6.23 & $4 \mathrm{H}-4,73-77$ & 29.73 & 8.94 \\
\hline $3 \mathrm{H}-1,29-31$ & 15.29 & 6.22 & $4 \mathrm{H}-4,98-102$ & 29.98 & 6.43 \\
\hline $3 \mathrm{H}-1,48-52$ & 15.48 & 6.01 & $4 \mathrm{H}-4,123-127$ & 30.23 & 5.16 \\
\hline $3 \mathrm{H}-1,69-71$ & 15.69 & 1.46 & $4 \mathrm{H}-4,146-150$ & 30.46 & 6.99 \\
\hline $3 \mathrm{H}-1,98-102$ & 15.98 & 1.92 & $4 \mathrm{H}-5,23-27$ & 30.73 & 5.71 \\
\hline $3 \mathrm{H}-1,103-105$ & 16.03 & 0.88 & $4 \mathrm{H}-5,48-52$ & 30.98 & 0.95 \\
\hline $3 \mathrm{H}-1,119-121$ & 16.19 & 7.06 & $4 \mathrm{H}-5,73-77$ & 31.23 & 0.71 \\
\hline $3 \mathrm{H}-1,130-132$ & 16.30 & 6.24 & $4 \mathrm{H}-5,98-102$ & 31.48 & 1.97 \\
\hline $3 \mathrm{H}-1,146-150$ & 16.46 & 11.90 & $4 \mathrm{H}-5,123-127$ & 31.73 & 8.09 \\
\hline $3 \mathrm{H}-2,4-6$ & 16.54 & 10.38 & $4 \mathrm{H}-5,146-150$ & 31.96 & 8.06 \\
\hline $3 \mathrm{H}-2,16-18$ & 16.66 & 4.98 & $4 \mathrm{H}-6,23-27$ & 32.23 & 1.89 \\
\hline $3 \mathrm{H}-2,28-30$ & 16.78 & 9.69 & $4 \mathrm{H}-6,48-52$ & 32.48 & 5.60 \\
\hline $3 \mathrm{H}-2,38-40$ & 16.88 & 10.13 & $4 \mathrm{H}-6,73-77$ & 32.73 & 1.20 \\
\hline $3 \mathrm{H}-2,48-50$ & 16.98 & 9.96 & $4 \mathrm{H}-6,98-102$ & 32.98 & 4.98 \\
\hline $3 \mathrm{H}-2,55-57$ & 17.05 & 8.54 & $4 \mathrm{H}-6,123-127$ & 33.23 & 2.11 \\
\hline $3 \mathrm{H}-2,69-71$ & 17.19 & 7.59 & $4 \mathrm{H}-6,146-150$ & 33.46 & 1.92 \\
\hline $3 \mathrm{H}-2,98-102$ & 17.48 & 7.01 & $4 \mathrm{H}-7,23-27$ & 33.73 & 3.41 \\
\hline $3 \mathrm{H}-2,128-130$ & 17.78 & 7.01 & $4 \mathrm{H}-7,48-52$ & 33.98 & 2.38 \\
\hline $3 \mathrm{H}-2,140-142$ & 17.90 & 4.63 & $5 \mathrm{H}-1,23-27$ & 34.23 & 4.69 \\
\hline $3 \mathrm{H}-2,146-150$ & 17.96 & 2.06 & $5 \mathrm{H}-1,48-50$ & 34.48 & 4.38 \\
\hline $3 \mathrm{H}-3,10-12$ & 18.10 & 2.95 & $5 \mathrm{H}-1,73-77$ & 34.73 & 1.06 \\
\hline $3 \mathrm{H}-3,26-28$ & 18.26 & 5.12 & $5 \mathrm{H}-1,98-102$ & 34.98 & 6.51 \\
\hline $3 \mathrm{H}-3,38-40$ & 18.38 & 5.14 & $5 \mathrm{H}-1,123-127$ & 35.25 & 6.52 \\
\hline $3 \mathrm{H}-3,48-52$ & 18.48 & 5.45 & $5 \mathrm{H}-1,146-150$ & 35.46 & 1.47 \\
\hline $3 \mathrm{H}-3,65-67$ & 18.65 & 6.92 & $5 \mathrm{H}-2,23-27$ & 35.73 & 8.22 \\
\hline $3 \mathrm{H}-3,98-102$ & 18.98 & 6.35 & $5 \mathrm{H}-2,48-52$ & 35.98 & 7.79 \\
\hline $3 \mathrm{H}-3,105-107$ & 19.05 & 7.90 & $5 \mathrm{H}-2,73-77$ & 36.23 & 4.68 \\
\hline $3 \mathrm{H}-3,110-114$ & 19.10 & 5.87 & $5 \mathrm{H}-2,98-102$ & 36.48 & 5.13 \\
\hline $3 \mathrm{H}-4,10-12$ & 19.60 & 8.71 & $5 \mathrm{H}-2,123-127$ & 36.73 & 1.83 \\
\hline $3 \mathrm{H}-4,26-28$ & 19.76 & 8.97 & $5 \mathrm{H}-2,146-150$ & 36.96 & 8.10 \\
\hline $3 \mathrm{H}-4,35-37$ & 19.85 & 8.14 & $5 \mathrm{H}-3,23-27$ & 37.23 & 7.94 \\
\hline $3 \mathrm{H}-4,48-52$ & 19.98 & 7.21 & $5 \mathrm{H}-3,48-52$ & 37.48 & 7.90 \\
\hline $3 \mathrm{H}-4,54-56$ & 20.04 & 6.88 & $5 \mathrm{H}-3,98-102$ & 37.98 & 7.19 \\
\hline $3 \mathrm{H}-4,98-102$ & 20.48 & 8.24 & $5 \mathrm{H}-3,146-150$ & 38.46 & 5.96 \\
\hline $3 \mathrm{H}-4,103-105$ & 20.53 & 6.22 & $5 \mathrm{H}-4,48-52$ & 38.98 & 4.56 \\
\hline $3 \mathrm{H}-4,114-116$ & 20.64 & 7.34 & $5 \mathrm{H}-4,98-102$ & 39.48 & 3.49 \\
\hline $3 \mathrm{H}-4,133-135$ & 20.83 & 5.51 & $5 \mathrm{H}-4,146-150$ & 39.96 & 3.49 \\
\hline $3 \mathrm{H}-4,146-150$ & 20.96 & 1.05 & $5 \mathrm{H}-5,48-52$ & 40.48 & 4.95 \\
\hline $3 \mathrm{H}-5,2-4$ & 21.02 & 1.66 & $5 \mathrm{H}-5,98-102$ & 40.98 & 3.59 \\
\hline $3 \mathrm{H}-5,27-29$ & 21.27 & 1.85 & & & \\
\hline
\end{tabular}

Table 3. Oxygen isotope values for sediments from Hole 680B.

\begin{tabular}{lcc}
\hline $\begin{array}{l}\text { Core, section, } \\
\text { interval (cm) }\end{array}$ & $\begin{array}{l}\text { Depth } \\
\text { (mbsf) }\end{array}$ & (\%o PDB) \\
\hline $112-680 \mathrm{~B}-1 \mathrm{H}-1,3-4$ & 0.03 & 1.57 \\
$1 \mathrm{H}-1,18-19$ & 0.18 & 1.63 \\
1H-1, 35-39 & 0.32 & 1.55 \\
$1 \mathrm{H}-1,40-41$ & 0.40 & 1.76 \\
$1 \mathrm{H}-1,48-52$ & 0.48 & 1.78 \\
$1 \mathrm{H}-1,52-53$ & 0.52 & 1.63 \\
$1 \mathrm{H}-1,65-66$ & 0.65 & 1.29 \\
$1 \mathrm{H}-1,73-77$ & 0.73 & 1.45 \\
$1 \mathrm{H}-1,87-88$ & 0.87 & 1.60 \\
$1 \mathrm{H}-1,112-113$ & 1.12 & 1.61 \\
$1 \mathrm{H}-1,123-125$ & 1.23 & 1.40 \\
$1 \mathrm{H}-1,131-132$ & 1.31 & 1.34 \\
$1 \mathrm{H}-1,146-150$ & 1.46 & 1.53 \\
$1 \mathrm{H}-2,14-16$ & 1.64 & 0.80 \\
$1 \mathrm{H}-2,23-27$ & 1.73 & 1.59 \\
$1 \mathrm{H}-2,29-31$ & 1.79 & 1.64 \\
$1 \mathrm{H}-2,41-43$ & 1.91 & 1.60 \\
$1 \mathrm{H}-2,48-52$ & 1.98 & 1.52 \\
$1 \mathrm{H}-2,54-56$ & 2.04 & 1.60 \\
$1 \mathrm{H}-3,23-27$ & 3.23 & 2.06 \\
$1 \mathrm{H}-3,48-52$ & 3.48 & 2.35 \\
$1 \mathrm{H}-3,73-77$ & 3.73 & 2.13 \\
$1 \mathrm{H}-3,83-84$ & 3.83 & 2.33 \\
$1 \mathrm{H}-3,98-102$ & 3.98 & 1.96 \\
$1 \mathrm{H}-3,123-127$ & 4.23 & 2.12 \\
$1 \mathrm{H}-3,146-150$ & 4.46 & 2.21 \\
$1 \mathrm{H}-4,23-27$ & 4.73 & 2.07 \\
$1 \mathrm{H}-4,43-44$ & 4.93 & 2.17 \\
$1 \mathrm{H}-4,48-52$ & 4.98 & 2.06 \\
& & \\
\hline
\end{tabular}


Table 3 (continued).

\begin{tabular}{|c|c|c|}
\hline $\begin{array}{l}\text { Core, section, } \\
\text { interval }(\mathrm{cm})\end{array}$ & $\begin{array}{l}\text { Depth } \\
\text { (mbsf) }\end{array}$ & $(\% \circ \mathrm{PDB})$ \\
\hline $1 \mathrm{H}-4,73-77$ & 5.23 & 1.93 \\
\hline $2 \mathrm{H}-1,23-27$ & 5.73 & 2.13 \\
\hline $2 \mathrm{H}-1,40-41$ & 5.90 & 2.09 \\
\hline $2 \mathrm{H}-1,48-50$ & 5.98 & 1.97 \\
\hline $2 \mathrm{H}-1,73-77$ & 6.23 & 2.04 \\
\hline $2 \mathrm{H}-1,87-88$ & 6.37 & 1.92 \\
\hline $2 \mathrm{H}-1,98-102$ & 6.48 & 1.92 \\
\hline $2 \mathrm{H}-1,123-127$ & 6.73 & 1.66 \\
\hline $2 \mathrm{H}-1,138-139$ & 6.88 & 1.70 \\
\hline $2 \mathrm{H}-1,146-150$ & 6.96 & 1.82 \\
\hline $2 \mathrm{H}-2,23-27$ & 7.23 & 1.60 \\
\hline $2 \mathrm{H}-2,40-41$ & 7.40 & 1.58 \\
\hline $2 \mathrm{H}-2,48-52$ & 7.48 & 1.43 \\
\hline $2 \mathrm{H}-2,73-77$ & 7.73 & 1.71 \\
\hline $2 \mathrm{H}-2,88-89$ & 7.88 & 1.58 \\
\hline $2 \mathrm{H}-2,98-102$ & 7.98 & 1.62 \\
\hline $2 \mathrm{H}-2,123-127$ & 8.23 & 1.55 \\
\hline $2 \mathrm{H}-2,135-136$ & 8.35 & 1.59 \\
\hline $2 \mathrm{H}-2,146-150$ & 8.64 & 1.70 \\
\hline $2 \mathrm{H}-3,23-27$ & 8.73 & 1.59 \\
\hline $2 \mathrm{H}-3,40-41$ & 8.90 & 1.72 \\
\hline $2 \mathrm{H}-3,48-52$ & 8.98 & 1.72 \\
\hline $2 \mathrm{H}-3,73-77$ & 9.23 & 1.82 \\
\hline $2 \mathrm{H}-3,88-89$ & 9.38 & 1.77 \\
\hline $2 \mathrm{H}-3,98-102$ & 9.48 & 1.83 \\
\hline $2 \mathrm{H}-3,123-127$ & 9.73 & 2.04 \\
\hline $2 \mathrm{H}-3,135-136$ & 9.85 & 2.06 \\
\hline $2 \mathrm{H}-4,23-27$ & 10.23 & 2.44 \\
\hline $2 \mathrm{H}-4,98-102$ & 10.98 & 2.35 \\
\hline $2 \mathrm{H}-4,123-127$ & 11.23 & 2.08 \\
\hline $2 \mathrm{H}-6,23-27$ & 13.23 & 2.28 \\
\hline $2 \mathrm{H}-6,48-52$ & 13.48 & 2.01 \\
\hline $2 \mathrm{H}-6,123-127$ & 14.23 & 1.61 \\
\hline $2 \mathrm{H}-6,146-150$ & 14.64 & 1.32 \\
\hline $2 \mathrm{H}-7,23-27$ & 14.73 & 1.54 \\
\hline $2 \mathrm{H}-7,66-70$ & 15.16 & 2.02 \\
\hline $3 \mathrm{H}-1,23-27$ & 15.23 & 1.93 \\
\hline $3 \mathrm{H}-1,146-150$ & 16.46 & 1.78 \\
\hline $3 \mathrm{H}-2,23-27$ & 16.73 & 2.05 \\
\hline $3 \mathrm{H}-2,48-52$ & 16.98 & 1.68 \\
\hline $3 \mathrm{H}-2,73-77$ & 17.73 & 2.05 \\
\hline $3 \mathrm{H}-2,146-150$ & 17.96 & 2.31 \\
\hline $3 \mathrm{H}-3,23-27$ & 18.23 & 2.11 \\
\hline $3 \mathrm{H}-3,48-52$ & 18.48 & 1.79 \\
\hline $3 \mathrm{H}-3,73-77$ & 18.73 & 2.14 \\
\hline $3 \mathrm{H}-3,98-102$ & 18.98 & 2.13 \\
\hline $3 \mathrm{H}-3,110-114$ & 19.10 & 2.03 \\
\hline $3 \mathrm{H}-4,23-27$ & 19.73 & 1.77 \\
\hline $3 \mathrm{H}-4,48-52$ & 19.98 & 1.87 \\
\hline $3 \mathrm{H}-4,73-77$ & 20.23 & 1.60 \\
\hline $3 \mathrm{H}-4,98-102$ & 20.48 & 1.75 \\
\hline $3 \mathrm{H}-4,123-127$ & 20.73 & 1.78 \\
\hline $3 \mathrm{H}-4,146-150$ & 20.96 & 1.65 \\
\hline $3 \mathrm{H}-5,23-27$ & 21.23 & 1.47 \\
\hline $3 \mathrm{H}-5,73-77$ & 21.73 & 1.56 \\
\hline $3 \mathrm{H}-5,98-102$ & 21.98 & 1.49 \\
\hline $3 \mathrm{H}-5,123-127$ & 22.23 & 1.60 \\
\hline $3 \mathrm{H}-5,146-150$ & 22.46 & 1.66 \\
\hline $3 \mathrm{H}-6,23-27$ & 22.73 & 1.67 \\
\hline $3 \mathrm{H}-6,73-77$ & 23.23 & 2.12 \\
\hline $3 \mathrm{H}-6,123-127$ & 23.73 & 2.58 \\
\hline $3 \mathrm{H}-7,23-27$ & 24.23 & 2.64 \\
\hline $3 \mathrm{H}-7,48-52$ & 24.48 & 2.72 \\
\hline $3 \mathrm{H}-7,62-66$ & 24.62 & 2.63 \\
\hline $4 \mathrm{H}-1,23-27$ & 24.73 & 2.12 \\
\hline $4 \mathrm{H}-1,48-52$ & 24.98 & 2.19 \\
\hline $4 \mathrm{H}-1,73-77$ & 25.23 & 1.83 \\
\hline $4 \mathrm{H}-1,98-102$ & 25.48 & 2.27 \\
\hline $4 \mathrm{H}-1,123-127$ & 25.73 & 2.32 \\
\hline $4 \mathrm{H}-1,146-150$ & 25.96 & 2.03 \\
\hline $4 \mathrm{H}-2,23-27$ & 26.23 & 1.75 \\
\hline $4 \mathrm{H}-2,48-52$ & 26.48 & 1.88 \\
\hline $4 \mathrm{H}-2,73-77$ & 26.73 & 1.82 \\
\hline $4 \mathrm{H}-2,98-102$ & 26.98 & 1.85 \\
\hline $4 \mathrm{H}-2,123-127$ & 27.23 & 1.79 \\
\hline $4 \mathrm{H}-2,146-150$ & 27.46 & 1.67 \\
\hline $4 \mathrm{H}-3,23-27$ & 27.73 & 1.69 \\
\hline $4 \mathrm{H}-3,48-52$ & 27.98 & 1.63 \\
\hline
\end{tabular}

Table 3 (continued).

\begin{tabular}{|c|c|c|}
\hline $\begin{array}{l}\text { Core, section, } \\
\text { interval }(\mathrm{cm})\end{array}$ & $\begin{array}{l}\text { Depth } \\
\text { (mbsf) }\end{array}$ & (\% PDB) \\
\hline $4 \mathrm{H}-3,73-77$ & 28.23 & 1.54 \\
\hline $4 \mathrm{H}-3,98-102$ & 28.48 & 1.65 \\
\hline $4 \mathrm{H}-3,123-127$ & 28.73 & 1.61 \\
\hline $4 \mathrm{H}-3,146-150$ & 28.96 & 1.37 \\
\hline $4 \mathrm{H}-4,23-27$ & 29.23 & 1.65 \\
\hline $4 \mathrm{H}-4,48-52$ & 29.48 & 1.61 \\
\hline $4 \mathrm{H}-4,73-77$ & 29.73 & 1.67 \\
\hline $4 \mathrm{H}-4,98-102$ & 29.98 & 1.56 \\
\hline $4 \mathrm{H}-4,123-127$ & 30.23 & 1.76 \\
\hline $4 \mathrm{H}-5,48-52$ & 30.98 & 2.70 \\
\hline $4 \mathrm{H}-5,73-77$ & 31.23 & 3.11 \\
\hline $4 \mathrm{H}-5,98-102$ & 31.48 & 2.99 \\
\hline $4 \mathrm{H}-5,123-127$ & 31.73 & 2.02 \\
\hline $4 \mathrm{H}-6,123-127$ & 33.23 & 1.68 \\
\hline $4 \mathrm{H}-7,23-27$ & 33.73 & 1.96 \\
\hline $4 \mathrm{H}-7,48-52$ & 33.98 & 2.30 \\
\hline $5 \mathrm{H}-2,23-27$ & 35.73 & 1.65 \\
\hline $5 \mathrm{H}-2,48-52$ & 35.98 & 2.22 \\
\hline $5 \mathrm{H}-2,73-77$ & 36.23 & 2.12 \\
\hline $5 \mathrm{H}-2,123-127$ & 36.73 & 1.76 \\
\hline $5 \mathrm{H}-3,48-52$ & 37.48 & 1.69 \\
\hline $5 \mathrm{H}-3,98-102$ & 37.98 & 1.28 \\
\hline $5 \mathrm{H}-4,23-27$ & 38.73 & 1.57 \\
\hline $5 \mathrm{H}-4,48-52$ & 38.98 & 1.36 \\
\hline $5 \mathrm{H}-4,73-77$ & 39.23 & 1.45 \\
\hline $5 \mathrm{H}-4,98-102$ & 39.48 & 1.42 \\
\hline $5 \mathrm{H}-4,123-127$ & 39.73 & 1.43 \\
\hline $5 \mathrm{H}-4,146-150$ & 39.96 & 1.68 \\
\hline $5 \mathrm{H}-5,23-27$ & 40.23 & 1.65 \\
\hline $5 \mathrm{H}-5,48-52$ & 40.48 & 1.84 \\
\hline $5 \mathrm{H}-5,73-77$ & 40.73 & 1.83 \\
\hline $5 \mathrm{H}-5,98-102$ & 40.98 & 1.88 \\
\hline $5 \mathrm{H}-5,123-127$ & 41.23 & 1.99 \\
\hline $5 \mathrm{H}-5,146-150$ & 41.46 & 1.92 \\
\hline $5 \mathrm{H}-6,23-27$ & 41.73 & 2.16 \\
\hline $5 \mathrm{H}-6,48-52$ & 41.98 & 2.13 \\
\hline $5 \mathrm{H}-6,73-77$ & 42.23 & 2.10 \\
\hline $5 \mathrm{H}-6,123-127$ & 42.73 & 2.13 \\
\hline $5 \mathrm{H}-6,146-150$ & 42.96 & 2.20 \\
\hline $5 \mathrm{H}-7,23-27$ & 43.23 & 2.25 \\
\hline
\end{tabular}

Table 4. Grain-size distribution of sediments from Hole 686B.

\begin{tabular}{lcc}
\hline $\begin{array}{l}\text { Core, section, } \\
\text { interval (cm) }\end{array}$ & $\begin{array}{c}\text { Depth } \\
\text { (mbsf) }\end{array}$ & $\begin{array}{c}\text { Fraction } \\
<32 \mu \mathrm{m} \\
\text { (wt\%) }\end{array}$ \\
\hline $\begin{array}{l}\text { 112-686B-1H-1, 0-3 } \\
\text { 1H-1, 18-20 }\end{array}$ & 0.00 & 74.39 \\
$1 \mathrm{H}-1,23-27$ & 0.18 & 72.92 \\
$1 \mathrm{H}-1,73-77$ & 0.23 & 90.02 \\
$1 \mathrm{H}-1,100-104$ & 0.73 & 79.14 \\
$1 \mathrm{H}-1,123-127$ & 1.00 & 83.51 \\
$1 \mathrm{H}-1,144-148$ & 1.23 & 87.54 \\
$1 \mathrm{H}-2,23-27$ & 1.44 & 88.14 \\
$1 \mathrm{H}-2,49-53$ & 1.73 & 56.76 \\
$1 \mathrm{H}-2,73-77$ & 1.99 & 87.81 \\
$1 \mathrm{H}-2,100-104$ & 2.23 & 93.65 \\
$1 \mathrm{H}-2,123-127$ & 2.50 & 95.83 \\
$1 \mathrm{H}-2,144-148$ & 2.73 & 96.56 \\
$1 \mathrm{H}-3,23-27$ & 2.94 & 93.62 \\
$1 \mathrm{H}-3,49-53$ & 3.23 & 91.59 \\
$1 \mathrm{H}-3,73-77$ & 3.49 & 74.66 \\
$1 \mathrm{H}-3,100-104$ & 3.73 & 82.83 \\
$1 \mathrm{H}-3,123-127$ & 4.00 & 90.73 \\
$1 \mathrm{H}-3,129-135$ & 4.23 & 83.82 \\
$1 \mathrm{H}-4,23-27$ & 4.29 & 66.20 \\
$1 \mathrm{H}-4,49-53$ & 4.73 & 71.19 \\
$1 \mathrm{H}-4,73-77$ & 4.99 & 84.95 \\
$1 \mathrm{H}-4,100-104$ & 5.23 & 89.80 \\
$1 \mathrm{H}-4,123-127$ & 5.50 & 91.89 \\
$1 \mathrm{H}-4,144-148$ & 5.73 & 93.70 \\
$1 \mathrm{H}-5,23-27$ & 5.94 & 89.67 \\
$1 \mathrm{H}-5,49-53$ & 6.23 & 87.18 \\
& 6.49 & 71.91
\end{tabular}

Table 4 (continued).

\begin{tabular}{|c|c|c|}
\hline $\begin{array}{l}\text { Core, section, } \\
\text { interval }(\mathrm{cm})\end{array}$ & $\begin{array}{l}\text { Depth } \\
\text { (mbsf) }\end{array}$ & $\begin{array}{l}\text { Fraction } \\
<32 \mu \mathrm{m} \\
(\mathrm{wt} \%)\end{array}$ \\
\hline $1 \mathrm{H}-5,100-104$ & 7.00 & 44.36 \\
\hline $1 \mathrm{H}-5,123-127$ & 7.23 & 77.26 \\
\hline $1 \mathrm{H}-5,144-148$ & 7.44 & 82.22 \\
\hline $1 \mathrm{H}-6,23-27$ & 7.73 & 79.97 \\
\hline $1 \mathrm{H}-6,49-53$ & 7.99 & 72.77 \\
\hline $1 \mathrm{H}-6,73-77$ & 8.23 & 78.13 \\
\hline $2 \mathrm{H}-1,25-29$ & 8.75 & 75.20 \\
\hline $2 \mathrm{H}-1,51-55$ & 9.01 & 75.74 \\
\hline $2 \mathrm{H}-1,74-79$ & 9.24 & 83.46 \\
\hline $2 \mathrm{H}-1,96-100$ & 9.46 & 56.15 \\
\hline $2 \mathrm{H}-1,125-129$ & 9.75 & 84.37 \\
\hline $2 \mathrm{H}-1,145-149$ & 9.95 & 76.59 \\
\hline $2 \mathrm{H}-2,25-29$ & 10.25 & 67.99 \\
\hline $2 \mathrm{H}-2,51-55$ & 10.51 & 74.38 \\
\hline $2 \mathrm{H}-2,74-79$ & 10.74 & 87.64 \\
\hline $2 \mathrm{H}-2,98-102$ & 10.98 & 81.92 \\
\hline $2 \mathrm{H}-2,125-129$ & 11.25 & 43.53 \\
\hline $2 \mathrm{H}-2,145-149$ & 11.45 & 76.74 \\
\hline $2 \mathrm{H}-3,25-29$ & 11.75 & 79.60 \\
\hline $2 \mathrm{H}-3,51-55$ & 12.01 & 82.45 \\
\hline $2 \mathrm{H}-3,74-79$ & 12.24 & 85.77 \\
\hline $2 \mathrm{H}-3,98-102$ & 12.48 & 78.74 \\
\hline $2 \mathrm{H}-3,125-129$ & 12.75 & 59.84 \\
\hline $2 \mathrm{H}-3,145-149$ & 12.95 & 64.78 \\
\hline $2 \mathrm{H}-4,25-29$ & 13.25 & 85.22 \\
\hline $2 \mathrm{H}-4,51-55$ & 13.51 & 84.01 \\
\hline $2 \mathrm{H}-4,74-79$ & 13.74 & 55.29 \\
\hline $2 \mathrm{H}-4,98-102$ & 13.98 & 76.01 \\
\hline $2 \mathrm{H}-4,125-129$ & 14.25 & 77.93 \\
\hline $2 \mathrm{H}-5,25-29$ & 14.75 & 81.69 \\
\hline $2 \mathrm{H}-5,51-55$ & 15.01 & 80.44 \\
\hline $2 \mathrm{H}-5,74-79$ & 15.24 & 77.30 \\
\hline $2 \mathrm{H}-5,98-102$ & 15.48 & 88.81 \\
\hline $2 \mathrm{H}-5,125-129$ & 15.75 & 84.82 \\
\hline $2 \mathrm{H}-5,145-149$ & 15.95 & 64.59 \\
\hline $2 \mathrm{H}-6,25-29$ & 16.25 & 76.76 \\
\hline $2 \mathrm{H}-6,51-55$ & 16.51 & 28.28 \\
\hline $2 \mathrm{H}-6,74-79$ & 16.74 & 37.47 \\
\hline $2 \mathrm{H}-6,98-102$ & 16.98 & 56.86 \\
\hline $2 \mathrm{H}-6,125-129$ & 17.25 & 58.15 \\
\hline $2 \mathrm{H}-6,145-149$ & 17.45 & 52.65 \\
\hline $2 \mathrm{H}-7,25-29$ & 17.75 & 43.67 \\
\hline $2 \mathrm{H}-7,51-55$ & 18.01 & 72.62 \\
\hline $3 \mathrm{H}-1,24-29$ & 18.24 & 91.98 \\
\hline $3 \mathrm{H}-1,49-54$ & 18.49 & 93.55 \\
\hline $3 \mathrm{H}-1,74-80$ & 18.74 & 96.81 \\
\hline $3 \mathrm{H}-1,99-104$ & 18.99 & 66.91 \\
\hline $3 \mathrm{H}-1,124-129$ & 19.24 & 95.40 \\
\hline $3 \mathrm{H}-1,145-149$ & 19.45 & 93.81 \\
\hline $3 \mathrm{H}-2,24-29$ & 19.74 & 94.93 \\
\hline $3 \mathrm{H}-2,49-54$ & 19.99 & 95.98 \\
\hline $3 \mathrm{H}-2,74-80$ & 20.24 & 96.08 \\
\hline $3 \mathrm{H}-2,99-104$ & 20.49 & 96.95 \\
\hline $3 \mathrm{H}-2,126-130$ & 20.76 & 95.88 \\
\hline $3 \mathrm{H}-2,145-149$ & 20.95 & 96.44 \\
\hline $3 \mathrm{H}-3,24-29$ & 21.24 & 89.90 \\
\hline $3 \mathrm{H}-3,49-54$ & 21.49 & 91.33 \\
\hline $3 \mathrm{H}-3,74-80$ & 21.74 & 93.29 \\
\hline $3 \mathrm{H}-3,99-104$ & 21.99 & 94.46 \\
\hline $3 \mathrm{H}-3,126-130$ & 22.26 & 12.32 \\
\hline $3 \mathrm{H}-4,24-29$ & 22.74 & 62.90 \\
\hline $3 \mathrm{H}-4,49-54$ & 22.99 & 76.20 \\
\hline $3 \mathrm{H}-4,74-80$ & 23.24 & 66.74 \\
\hline $3 \mathrm{H}-4,98-103$ & 23.48 & 91.57 \\
\hline $3 \mathrm{H}-4,126-130$ & 23.76 & 70.18 \\
\hline $3 \mathrm{H}-4,145-149$ & 23.95 & 85.62 \\
\hline $3 \mathrm{H}-5,24-29$ & 24.24 & 69.45 \\
\hline $3 \mathrm{H}-5,48-53$ & 24.48 & 53.46 \\
\hline $3 \mathrm{H}-5,74-80$ & 24.74 & 46.05 \\
\hline $3 \mathrm{H}-5,97-102$ & 24.97 & 52.64 \\
\hline $3 \mathrm{H}-5,126-130$ & 25.26 & 51.55 \\
\hline $3 \mathrm{H}-6,24-29$ & 25.74 & 38.82 \\
\hline $3 \mathrm{H}-6,49-54$ & 25.99 & 55.24 \\
\hline $3 \mathrm{H}-6,74-80$ & 26.24 & 43.62 \\
\hline $3 \mathrm{H}-6,98-103$ & 26.48 & 44.27 \\
\hline $3 \mathrm{H}-6,145-149$ & 26.95 & 53.29 \\
\hline 3 H- $7,24-29$ & 27.24 & 33.40 \\
\hline
\end{tabular}


Table 4 (continued).

\begin{tabular}{|c|c|c|}
\hline $\begin{array}{l}\text { Core, section, } \\
\text { interval }(\mathrm{cm})\end{array}$ & $\begin{array}{l}\text { Depth } \\
\text { (mbsf) }\end{array}$ & $\begin{array}{c}\text { Fraction } \\
<32 \mu \mathrm{m} \\
(\mathrm{wt} \%)\end{array}$ \\
\hline $3 \mathrm{H}-7,48-53$ & 27.48 & 41.87 \\
\hline $4 \mathrm{H}-1,24-28$ & 27.74 & 60.48 \\
\hline $4 \mathrm{H}-1,50-54$ & 28.00 & 24.54 \\
\hline $4 \mathrm{H}-1,67-71$ & 28.17 & 46.42 \\
\hline $4 \mathrm{H}-5,24-28$ & 33.74 & 45.90 \\
\hline $4 \mathrm{H}-5,50-54$ & 34.00 & 44.78 \\
\hline $4 \mathrm{H}-5,67-71$ & 34.17 & 33.32 \\
\hline $4 \mathrm{H}-5,92-96$ & 34.42 & 49.84 \\
\hline $5 \mathrm{H}-1,23-27$ & 37.23 & 85.57 \\
\hline $5 \mathrm{H}-1,48-52$ & 37.48 & 79.50 \\
\hline $5 \mathrm{H}-1,71-75$ & 37.71 & 67.32 \\
\hline $5 \mathrm{H}-1,98-102$ & 37.98 & 86.16 \\
\hline $5 \mathrm{H}-1,124-128$ & 38.24 & 89.80 \\
\hline $5 \mathrm{H}-1,146-150$ & 38.46 & 90.67 \\
\hline $5 \mathrm{H}-2,23-27$ & 38.73 & 84.51 \\
\hline $5 \mathrm{H}-2,48-52$ & 38.98 & 40.73 \\
\hline $5 \mathrm{H}-2,71-75$ & 39.21 & 32.50 \\
\hline $5 \mathrm{H}-2,98-102$ & 39.48 & 23.93 \\
\hline $5 \mathrm{H}-2,124-128$ & 39.74 & 25.77 \\
\hline $5 \mathrm{H}-2,146-150$ & 39.96 & 85.95 \\
\hline $5 \mathrm{H}-3,23-27$ & 40.23 & 86.73 \\
\hline $5 \mathrm{H}-3,48-52$ & 40.48 & 90.58 \\
\hline $5 \mathrm{H}-3,71-75$ & 40.71 & 91.64 \\
\hline $5 \mathrm{H}-3,98-102$ & 40.98 & 84.20 \\
\hline $5 \mathrm{H}-3,124-128$ & 41.24 & 87.66 \\
\hline $5 \mathrm{H}-3,141-145$ & 41.41 & 89.95 \\
\hline $5 \mathrm{H}-4,23-27$ & 41.73 & 89.66 \\
\hline $5 \mathrm{H}-4,48-52$ & 41.98 & 91.33 \\
\hline $5 \mathrm{H}-4,71-75$ & 42.21 & 90.06 \\
\hline $5 \mathrm{H}-4,98-102$ & 42.48 & 91.93 \\
\hline $5 \mathrm{H}-4,124-128$ & 42.74 & 93.83 \\
\hline $5 \mathrm{H}-4,146-150$ & 42.96 & 94.06 \\
\hline $5 \mathrm{H}-5,23-27$ & 43.23 & 89.35 \\
\hline $5 \mathrm{H}-5,48-52$ & 43.48 & 84.79 \\
\hline $5 \mathrm{H}-5,71-75$ & 43.71 & 89.50 \\
\hline $5 \mathrm{H}-5,98-102$ & 43.98 & 90.42 \\
\hline $5 \mathrm{H}-5,124-128$ & 44.24 & 93.48 \\
\hline $5 \mathrm{H}-5,146-150$ & 44.46 & 88.33 \\
\hline $5 \mathrm{H}-6,23-27$ & 44.73 & 89.08 \\
\hline $5 \mathrm{H}-6,48-52$ & 44.98 & 92.32 \\
\hline $5 \mathrm{H}-6,71-75$ & 45.21 & 88.08 \\
\hline $5 \mathrm{H}-6,98-102$ & 45.48 & 89.66 \\
\hline $5 \mathrm{H}-6,124-128$ & 45.74 & 76.10 \\
\hline $5 \mathrm{H}-6,146-150$ & 45.96 & 76.63 \\
\hline $5 \mathrm{H}-7,23-27$ & 46.23 & 91.81 \\
\hline $5 \mathrm{H}-7,48-52$ & 46.48 & 19.75 \\
\hline $6 X-1,24-29$ & 46.74 & 85.58 \\
\hline $6 \mathrm{X}-1,49-52$ & 46.99 & 91.28 \\
\hline $6 \mathrm{X}-1,74-78$ & 47.24 & 93.54 \\
\hline $6 \mathrm{X}-1,98-103$ & 47.48 & 88.14 \\
\hline $6 \mathrm{X}-1,122-126$ & 47.72 & 85.67 \\
\hline $6 \mathrm{X}-2,24-29$ & 48.24 & 83.97 \\
\hline $6 \mathrm{X}-2,49-52$ & 48.49 & 92.16 \\
\hline $6 X-2,74-78$ & 48.74 & 93.43 \\
\hline $6 \times-2,98-103$ & 48.98 & 83.42 \\
\hline $6 \mathrm{X}-2,122-126$ & 49.22 & 92.58 \\
\hline $6 \mathrm{X}-3,24-29$ & 49.74 & 94.57 \\
\hline $6 X-3,49-52$ & 49.99 & 90.05 \\
\hline $6 X-3,74-78$ & 50.24 & 92.22 \\
\hline $6 X-3,122-126$ & 50.72 & 93.32 \\
\hline $6 \times-3,143-147$ & 50.93 & 84.60 \\
\hline $6 \mathrm{X}-4,24-29$ & 51.24 & 83.93 \\
\hline $6 \mathrm{X}-4,49-52$ & 51.49 & 61.61 \\
\hline $7 X-1,24-28$ & 56.24 & 38.72 \\
\hline $7 X-1,49-54$ & 56.49 & 35.60 \\
\hline $7 X-1,75-79$ & 56.75 & 51.24 \\
\hline $7 X-1,98-103$ & 56.98 & 47.76 \\
\hline $7 X-1,143-147$ & 57.43 & 47.09 \\
\hline $8 X-1,22-26$ & 65.72 & 25.74 \\
\hline $8 X-1,47-51$ & 65.97 & 25.74 \\
\hline $8 X-1,72-76$ & 66.22 & 24.38 \\
\hline $8 X-1,98-102$ & 66.48 & 35.23 \\
\hline $8 X-2,22-26$ & 67.22 & 47.23 \\
\hline $8 X-2,47-51$ & 67.47 & 47.24 \\
\hline $8 X-2,98-102$ & 67.98 & 36.87 \\
\hline $8 X-2,122-126$ & 68.22 & 79.53 \\
\hline $8 X-3,22-26$ & 68.72 & 14.51 \\
\hline
\end{tabular}

Table 4 (continued).

\begin{tabular}{|c|c|c|}
\hline $\begin{array}{l}\text { Core, section, } \\
\text { interval }(\mathrm{cm})\end{array}$ & $\begin{array}{l}\text { Depth } \\
\text { (mbsf) }\end{array}$ & $\begin{array}{c}\text { Fraction } \\
<32 \mu \mathrm{m} \\
(\mathrm{wt} \%)\end{array}$ \\
\hline $8 X-3,47-51$ & 68.97 & 50.93 \\
\hline $8 X-3,72-76$ & 69.22 & 80.33 \\
\hline $8 X-3,98-102$ & 69.48 & 85.18 \\
\hline $8 X-3,128-131$ & 69.78 & 83.28 \\
\hline $8 X-3,146-150$ & 69.96 & 86.40 \\
\hline $8 X-4,22-26$ & 70.22 & 79.41 \\
\hline $8 X-4,47-51$ & 70.47 & 85.05 \\
\hline $8 X-4,72-76$ & 70.72 & 86.06 \\
\hline $8 X-4,98-102$ & 70.98 & 88.23 \\
\hline $8 X-4,122-126$ & 71.22 & 61.97 \\
\hline $9 X-1,24-28$ & 75.24 & 81.50 \\
\hline $9 X-2,24-28$ & 75.52 & 89.27 \\
\hline $9 X-2,49-54$ & 75.77 & 87.63 \\
\hline $9 X-2,69-74$ & 75.97 & 90.91 \\
\hline $9 X-3,24-28$ & 77.02 & 89.93 \\
\hline $9 X-3,72-77$ & 77.50 & 83.53 \\
\hline $9 \times-3,124-129$ & 78.02 & 50.12 \\
\hline $9 X-4,20-23$ & 78.48 & 29.05 \\
\hline $9 X-4,72-77$ & 79.00 & 63.54 \\
\hline $9 X-4,124-129$ & 79.52 & 72.31 \\
\hline $9 X-5,20-25$ & 79.98 & 81.37 \\
\hline $9 X-5,49-54$ & 80.27 & 54.93 \\
\hline $9 X-5,72-77$ & 80.50 & 62.70 \\
\hline $9 X-5,124-129$ & 81.02 & 91.18 \\
\hline $9 X-6,23-28$ & 81.51 & 90.72 \\
\hline $9 X-6,49-54$ & 81.77 & 94.80 \\
\hline $9 X-6,72-77$ & 82.00 & 92.69 \\
\hline $9 X-7,20-25$ & 82.98 & 92.56 \\
\hline $9 X-7,49-54$ & 83.27 & 88.44 \\
\hline $9 \times-7,72-77$ & 83.50 & 90.21 \\
\hline $9 X-7,96-101$ & 83.74 & 90.84 \\
\hline $10 X-1,24-28$ & 84.74 & 92.75 \\
\hline $10 X-1,48-52$ & 84.98 & 92.92 \\
\hline $10 X-1,74-78$ & 85.24 & 95.53 \\
\hline
\end{tabular}

Table 5. Organic carbon content of sediments from Hole 686B.

\begin{tabular}{|c|c|c|}
\hline $\begin{array}{l}\text { Core, section, } \\
\text { interval }(\mathrm{cm})\end{array}$ & $\begin{array}{l}\text { Depth } \\
\text { (mbsf) }\end{array}$ & $\begin{array}{l}\mathrm{C}_{\text {org }} \\
\text { (wt\%) }\end{array}$ \\
\hline $112-686 \mathrm{~B}-1 \mathrm{H}-1,49-53$ & 0.49 & 2.45 \\
\hline $1 \mathrm{H}-1,100-104$ & 1.00 & 1.31 \\
\hline $1 \mathrm{H}-1,144-148$ & 1.40 & 2.13 \\
\hline $1 \mathrm{H}-2,49-53$ & 1.99 & 2.69 \\
\hline $1 \mathrm{H}-2,100-104$ & 2.50 & 3.36 \\
\hline $1 \mathrm{H}-2,144-148$ & 2.94 & 3.35 \\
\hline $1 \mathrm{H}-3,49-53$ & 3.49 & 2.04 \\
\hline $1 \mathrm{H}-3,100-104$ & 4.00 & 3.87 \\
\hline $1 \mathrm{H}-3,135-129$ & 4.35 & 2.41 \\
\hline $1 \mathrm{H}-4,49-53$ & 4.99 & 3.60 \\
\hline $1 \mathrm{H}-4,100-104$ & 5.50 & 3.47 \\
\hline $1 \mathrm{H}-4,144-148$ & 5.94 & 3.46 \\
\hline $1 \mathrm{H}-5,49-53$ & 6.49 & 2.29 \\
\hline $1 \mathrm{H}-5,100-104$ & 7.00 & 1.87 \\
\hline $1 \mathrm{H}-5,144-148$ & 7.40 & 2.54 \\
\hline $1 \mathrm{H}-6,49-53$ & 7.99 & 1.95 \\
\hline $2 \mathrm{H}-1,51-55$ & 9.01 & 2.44 \\
\hline $2 \mathrm{H}-1,96-100$ & 9.46 & 2.20 \\
\hline $2 \mathrm{H}-1,145-149$ & 9.95 & 2.65 \\
\hline $2 \mathrm{H}-2,51-55$ & 10.51 & 2.89 \\
\hline $2 \mathrm{H}-2,98-102$ & 10.98 & 2.28 \\
\hline $2 \mathrm{H}-2,145-149$ & 11.45 & 2.26 \\
\hline $2 \mathrm{H}-3,51-55$ & 12.01 & 2.17 \\
\hline $2 \mathrm{H}-3,98-102$ & 12.48 & 2.44 \\
\hline $2 \mathrm{H}-3,145-149$ & 12.95 & 4.15 \\
\hline $2 \mathrm{H}-4,51-55$ & 13.51 & 3.60 \\
\hline $2 \mathrm{H}-4,98-102$ & 13.98 & 3.75 \\
\hline $2 \mathrm{H}-5,51-55$ & 15.01 & 5.19 \\
\hline $2 \mathrm{H}-5,98-102$ & 15.48 & 3.58 \\
\hline $2 \mathrm{H}-5,145-149$ & 15.19 & 2.83 \\
\hline $2 \mathrm{H}-6,51-55$ & 16.51 & 1.05 \\
\hline $2 \mathrm{H}-6,98-102$ & 16.98 & 1.57 \\
\hline $2 \mathrm{H}-6,145-149$ & 17.45 & 1.67 \\
\hline
\end{tabular}

Table 5 (continued).

\begin{tabular}{|c|c|c|}
\hline $\begin{array}{l}\text { Core, section, } \\
\text { interval }(\mathrm{cm})\end{array}$ & $\begin{array}{l}\text { Depth } \\
\text { (mbsf) }\end{array}$ & $\begin{array}{l}\mathrm{C}_{\mathrm{org}} \\
(\mathrm{wt} \%)\end{array}$ \\
\hline $2 \mathrm{H}-7,51-55$ & 18.01 & 1.53 \\
\hline $3 \mathrm{H}-1,49-54$ & 18.49 & 1.76 \\
\hline $3 \mathrm{H}-1,99-104$ & 18.99 & 2.14 \\
\hline $3 \mathrm{H}-1,145-149$ & 19.45 & 1.14 \\
\hline $3 \mathrm{H}-2,49-54$ & 19.99 & 1.43 \\
\hline $3 \mathrm{H}-2,99-104$ & 20.49 & 1.62 \\
\hline $3 \mathrm{H}-2,145-149$ & 20.95 & 1.65 \\
\hline $3 \mathrm{H}-3,49-54$ & 21.49 & 1.56 \\
\hline $3 \mathrm{H}-3,99-104$ & 21.99 & 1.03 \\
\hline $3 \mathrm{H}-4,49-54$ & 22.99 & 1.27 \\
\hline $3 \mathrm{H}-4,98-103$ & 23.48 & 0.86 \\
\hline $3 \mathrm{H}-4,145-149$ & 23.95 & 1.09 \\
\hline $3 \mathrm{H}-5,48-53$ & 24.48 & 0.44 \\
\hline $3 \mathrm{H}-5,97-102$ & 24.97 & 0.71 \\
\hline $3 \mathrm{H}-6,49-54$ & 25.99 & 0.68 \\
\hline $3 \mathrm{H}-6,98-103$ & 26.48 & 0.57 \\
\hline $3 \mathrm{H}-6,145-149$ & 26.95 & 0.70 \\
\hline $3 \mathrm{H}-7,48-53$ & 27.48 & 1.12 \\
\hline $4 \mathrm{H}-1,50-54$ & 28.00 & 0.64 \\
\hline $4 \mathrm{H}-5,50-54$ & 34.00 & 0.82 \\
\hline $4 \mathrm{H}-5,92-96$ & 34.42 & 1.15 \\
\hline $5 \mathrm{H}-1,48-52$ & 37.48 & 2.34 \\
\hline $5 \mathrm{H}-1,98-102$ & 37.98 & 2.26 \\
\hline $5 \mathrm{H}-1,146-150$ & 38.46 & 2.31 \\
\hline $5 \mathrm{H}-2,48-52$ & 38.98 & 0.62 \\
\hline $5 \mathrm{H}-2,98-102$ & 39.48 & 0.41 \\
\hline $5 \mathrm{H}-2,146-150$ & 39.96 & 5.06 \\
\hline $5 \mathrm{H}-3,48-52$ & 40.48 & 6.27 \\
\hline $5 \mathrm{H}-3,98-102$ & 40.98 & 5.92 \\
\hline $5 \mathrm{H}-3,141-145$ & 41.41 & 2.67 \\
\hline $5 \mathrm{H}-4,48-52$ & 41.98 & 2.93 \\
\hline $5 \mathrm{H}-4,98-102$ & 42.48 & 3.43 \\
\hline $5 \mathrm{H}-4,146-150$ & 42.96 & 3.10 \\
\hline $5 \mathrm{H}-5,48-52$ & 43.48 & 2.64 \\
\hline $5 \mathrm{H}-5,98-102$ & 43.98 & 2.30 \\
\hline $5 \mathrm{H}-5,146-150$ & 44.46 & 2.15 \\
\hline $5 \mathrm{H}-6,48-52$ & 44.98 & 2.06 \\
\hline $5 \mathrm{H}-6,98-102$ & 45.48 & 1.66 \\
\hline $5 \mathrm{H}-6,146-150$ & 45.96 & 1.21 \\
\hline $5 \mathrm{H}-7,48-52$ & 46.48 & 0.53 \\
\hline $6 \times-1,49-52$ & 46.99 & 5.42 \\
\hline $6 \mathrm{X}-1,98-103$ & 47.48 & 4.22 \\
\hline $6 \times-2,49-52$ & 48.49 & 2.43 \\
\hline $6 X-2,98-103$ & 48.98 & 2.16 \\
\hline $6 \mathrm{X}-3,49-52$ & 49.99 & 1.97 \\
\hline $6 X-3,143-147$ & 50.93 & 1.51 \\
\hline $6 X-4,49-52$ & 51.49 & 1.09 \\
\hline $7 X-1,49-54$ & 56.49 & 0.37 \\
\hline $7 X-1,98-103$ & 56.98 & 0.59 \\
\hline $7 X-1,143-147$ & 57.43 & 0.41 \\
\hline $8 X-1,47-51$ & 65.97 & 0.16 \\
\hline $8 X-1,98-102$ & 66.48 & 0.80 \\
\hline $8 X-2,47-51$ & 67.47 & 0.80 \\
\hline $8 X-2,98-102$ & 67.98 & 0.95 \\
\hline $8 X-3,47-51$ & 68.97 & 2.80 \\
\hline $8 X-3,98-102$ & 69.48 & 4.90 \\
\hline $8 X-3,146-150$ & 69.96 & 3.66 \\
\hline $8 X-4,47-51$ & 70.47 & 3.41 \\
\hline $8 X-4,98-102$ & 70.98 & 3.39 \\
\hline $9 X-2,49-54$ & 75.77 & 1.21 \\
\hline $9 X-3,96-101$ & 77.74 & 1.02 \\
\hline $9 X-4,96-101$ & 79.24 & 2.65 \\
\hline $9 X-4,148-150$ & 79.76 & 2.23 \\
\hline $9 X-5,49-54$ & 80.27 & 2.48 \\
\hline $9 X-5,96-101$ & 80.74 & 2.20 \\
\hline $9 X-6,49-54$ & 81.77 & 2.73 \\
\hline $9 X-6,96-101$ & 82.24 & 2.80 \\
\hline $9 X-7,49-54$ & 83.27 & 2.90 \\
\hline $9 X-7,96-101$ & 83.74 & 2.18 \\
\hline $10 \times-1,48-52$ & 84.98 & 1.93 \\
\hline $10 \mathrm{X}-1,97-101$ & 85.47 & 1.09 \\
\hline $10 X-1,146-150$ & 85.96 & 1.52 \\
\hline $10 \times-2,48-52$ & 86.48 & 1.38 \\
\hline $10 \times-3,48-52$ & 87.98 & 1.46 \\
\hline $10 X-3,97-101$ & 88.47 & 1.82 \\
\hline $10 \times-3,146-150$ & 88.96 & 2.23 \\
\hline $10 X-4,48-52$ & 89.48 & 1.76 \\
\hline $10 \mathrm{X}-4,97-101$ & 89.97 & 0.75 \\
\hline
\end{tabular}


Table 5 (continued).

\begin{tabular}{|c|c|c|}
\hline $\begin{array}{l}\text { Core, section, } \\
\text { interval }(\mathrm{cm})\end{array}$ & $\begin{array}{l}\text { Depth } \\
\text { (mbsf) }\end{array}$ & $\begin{array}{l}\mathrm{C}_{\mathrm{org}} \\
\text { (wt\%) }\end{array}$ \\
\hline $11 X-1,48-52$ & 94.48 & 1.10 \\
\hline $11 X-2,48-52$ & 95.31 & 0.99 \\
\hline $11 X-2,98-102$ & 95.81 & 0.31 \\
\hline $11 X-2,142-146$ & 96.25 & 1.34 \\
\hline $11 X-3,48-52$ & 96.81 & 1.33 \\
\hline $11 X-3,98-102$ & 97.31 & 1.10 \\
\hline $11 X-3,142-146$ & 97.75 & 1.10 \\
\hline $11 X-4,142-146$ & 99.25 & 1.95 \\
\hline $11 X-5,48-52$ & 99.81 & 1.84 \\
\hline $11 X-5,98-102$ & 100.31 & 1.46 \\
\hline $11 X-5,142-146$ & 100.75 & 2.62 \\
\hline $11 X-6,48-52$ & 101.31 & 2.94 \\
\hline $11 X-6,98-102$ & 101.81 & 1.50 \\
\hline $11 X-6,144-148$ & 102.27 & 2.19 \\
\hline $11 X-7,48-52$ & 102.81 & 2.34 \\
\hline $11 X-7,98-102$ & 103.31 & 3.95 \\
\hline $11 X-7,144-148$ & 103.77 & 4.90 \\
\hline $11 X-8,38-42$ & 104.21 & 4.30 \\
\hline $12 X-1,50-54$ & 104.00 & 3.32 \\
\hline $12 X-1,100-104$ & 104.50 & 2.86 \\
\hline $12 X-1,146-150$ & 104.96 & 2.26 \\
\hline $12 X-2,50-54$ & 105.50 & 1.50 \\
\hline $12 X-2,100-104$ & 106.00 & 1.58 \\
\hline $12 X-3,50-54$ & 107.00 & 0.58 \\
\hline $12 X-3,100-104$ & 107.50 & 0.49 \\
\hline $12 X-4,100-104$ & 109.00 & 1.17 \\
\hline $13 \mathrm{X}-1,38-42$ & 113.38 & 0.45 \\
\hline $14 X-1,50-54$ & 123.00 & 2.41 \\
\hline $14 X-1,100-104$ & 123.50 & 2.19 \\
\hline $14 X-1,146-150$ & 123.96 & 1.95 \\
\hline $14 X-2,50-54$ & 124.50 & 2.15 \\
\hline $14 X-2,98-102$ & 124.98 & 2.48 \\
\hline $14 X-2,146-150$ & 125.46 & 3.06 \\
\hline $14 X-3,50-54$ & 126.00 & 2.98 \\
\hline $14 X-3,104-108$ & 126.54 & 3.63 \\
\hline $14 X-4,41-45$ & 127.41 & 2.35 \\
\hline $14 X-4,100-104$ & 128.00 & 3.67 \\
\hline $14 X-4,146-150$ & 128.46 & 2.57 \\
\hline $14 X-5,41-45$ & 128.91 & 2.94 \\
\hline $14 X-5,100-104$ & 129.50 & 3.32 \\
\hline $14 X-5,146-150$ & 129.96 & 3.63 \\
\hline $14 X-6,41-45$ & 130.41 & 2.96 \\
\hline $14 X-6,100-104$ & 131.00 & 3.28 \\
\hline $14 X-6,146-150$ & 131.46 & 3.57 \\
\hline $14 X-7,41-45$ & 131.91 & 4.15 \\
\hline $15 X-1,50-54$ & 132.50 & 2.59 \\
\hline $15 X-1,100-104$ & 133.00 & 2.61 \\
\hline $15 X-1,146-150$ & 133.46 & 4.19 \\
\hline $15 X-2,50-54$ & 134.00 & 3.19 \\
\hline $15 X-3,50-54$ & 135.50 & 2.89 \\
\hline $15 X-3,100-104$ & 136.00 & 2.95 \\
\hline $15 X-3,146-150$ & 136.46 & 5.45 \\
\hline $15 X-4,50-54$ & 137.00 & 3.60 \\
\hline $15 X-4,100-104$ & 137.50 & 3.97 \\
\hline $15 X-4,146-150$ & 137.96 & 4.05 \\
\hline $15 X-5,50-54$ & 138.00 & 3.73 \\
\hline $15 X-5,100-104$ & 139.00 & 1.36 \\
\hline $15 X-6,50-54$ & 140.00 & 1.37 \\
\hline $15 X-6,100-104$ & 140.50 & 0.89 \\
\hline $15 X-7,50-54$ & 141.98 & 2.05 \\
\hline $16 \mathrm{X}-1,100-104$ & 142.50 & 1.58 \\
\hline $16 X-1,146-150$ & 142.96 & 1.61 \\
\hline $16 \mathrm{X}-2,48-52$ & 143.48 & 2.25 \\
\hline $16 X-2,100-104$ & 144.00 & 2.77 \\
\hline $16 X-2,146-150$ & 144.46 & 2.58 \\
\hline $16 \mathrm{X}-3,48-52$ & 144.98 & 2.32 \\
\hline $16 X-3,100-104$ & 145.50 & 2.31 \\
\hline $16 X-3,146-150$ & 145.96 & 2.10 \\
\hline $16 \times-4,48-52$ & 146.48 & 2.29 \\
\hline $16 X-4,100-104$ & 147.00 & 1.98 \\
\hline $16 X-4,146-150$ & 147.46 & 2.01 \\
\hline $16 X-5,48-52$ & 147.98 & 1.67 \\
\hline $16 X-5,100-104$ & 148.50 & 1.56 \\
\hline $16 X-5,146-150$ & 148.96 & 1.82 \\
\hline $16 X-6,48-52$ & 149.48 & 2.25 \\
\hline $16 X-6,100-104$ & 150.00 & 1.99 \\
\hline $16 X-6,146-150$ & 50.46 & 1.95 \\
\hline $16 X-7,45-51$ & 150.91 & 1.66 \\
\hline
\end{tabular}

Table 5 (continued).

\begin{tabular}{|c|c|c|}
\hline $\begin{array}{l}\text { Core, section, } \\
\text { interval }(\mathrm{cm})\end{array}$ & $\begin{array}{l}\text { Depth } \\
\text { (mbsf) }\end{array}$ & $\begin{array}{l}\mathrm{C}_{\mathrm{org}} \\
(\mathrm{wt} \%)\end{array}$ \\
\hline $17 X-1,100-104$ & 152.00 & 1.20 \\
\hline $17 \mathrm{X}-1,144-146$ & 152.40 & 1.11 \\
\hline $17 \mathrm{X}-2,50-54$ & 153.00 & 1.17 \\
\hline $17 X-2,100-104$ & 153.50 & 1.00 \\
\hline $17 \mathrm{X}-2,144-146$ & 153.94 & 0.59 \\
\hline $17 \mathrm{X}-3,100-104$ & 155.00 & 0.86 \\
\hline $17 \mathrm{X}-3,144-146$ & 155.44 & 0.92 \\
\hline $17 X-4,50-54$ & 156.00 & 1.00 \\
\hline $17 \mathrm{X}-4,100-104$ & 156.50 & 1.82 \\
\hline $17 X-4,144-146$ & 156.94 & 2.09 \\
\hline $17 \mathrm{X}-5,50-54$ & 157.50 & 2.14 \\
\hline $17 \mathrm{X}-5,100-104$ & 158.00 & 0.81 \\
\hline $17 X-5,144-146$ & 158.44 & 0.83 \\
\hline $17 X-6,50-54$ & 159.00 & 2.18 \\
\hline $18 \mathrm{X}-1,50-54$ & 161.00 & 2.22 \\
\hline $18 X-2,50-54$ & 161.81 & 2.33 \\
\hline $18 X-2,100-104$ & 162.31 & 2.58 \\
\hline $18 X-3,50-54$ & 163.31 & 2.18 \\
\hline $18 \mathrm{X}-3,100-104$ & 163.81 & 2.36 \\
\hline $18 X-3,145-149$ & 164.26 & 1.95 \\
\hline $18 X-4,50-54$ & 164.81 & 1.99 \\
\hline $18 X-4,100-104$ & 165.31 & 1.87 \\
\hline $18 X-4,145-149$ & 165.76 & 3.17 \\
\hline $18 \mathrm{X}-5,50-54$ & 166.31 & 3.09 \\
\hline $18 X-5,100-104$ & 166.81 & 2.75 \\
\hline $18 X-5,145-149$ & 167.26 & 2.81 \\
\hline $18 X-6,50-54$ & 167.81 & 2.38 \\
\hline $18 X-6,100-104$ & 168.31 & 3.03 \\
\hline $18 X-7,50-54$ & 169.31 & 2.84 \\
\hline $18 X-7,100-104$ & 169.81 & 2.42 \\
\hline $18 X-7,145-149$ & 170.26 & 2.57 \\
\hline
\end{tabular}

Table 6. Oxygen isotope values for sediments from Hole 686B.

\begin{tabular}{|c|c|c|}
\hline $\begin{array}{l}\text { Core, section, } \\
\text { interval }(\mathrm{cm})\end{array}$ & $\begin{array}{l}\text { Depth } \\
\text { (mbsf) }\end{array}$ & (\%० PDB) \\
\hline $112-686 \mathrm{~B}-7 \mathrm{X}-1,75-79$ & 56.75 & 2.67 \\
\hline $8 X-1,22-26$ & 65.72 & 2.96 \\
\hline $8 X-2,22-26$ & 67.22 & 2.50 \\
\hline $8 X-2,122-126$ & 68.22 & 2.36 \\
\hline $8 X-3,72-76$ & 69.22 & 2.05 \\
\hline $8 X-3,128-131$ & 69.78 & 2.01 \\
\hline $8 X-4,72-76$ & 70.72 & 2.10 \\
\hline $9 X-1,24-28$ & 75.24 & 2.25 \\
\hline $9 X-2,24-28$ & 75.52 & 2.36 \\
\hline $9 \times-2,69-74$ & 75.97 & 2.40 \\
\hline $9 X-3,24-28$ & 77.02 & 2.50 \\
\hline $9 \times-3,72-77$ & 77.50 & 2.44 \\
\hline $9 X-6,72-77$ & 82.00 & 2.09 \\
\hline $9 X-7,20-25$ & 82.98 & 2.30 \\
\hline $9 X-7,72-77$ & 83.50 & 2.10 \\
\hline $10 \times-1,74-78$ & 85.24 & 2.36 \\
\hline $10 \mathrm{X}-1,124-128$ & 85.74 & 2.51 \\
\hline $10 X-2,24-26$ & 86.24 & 2.62 \\
\hline $10 X-2,124-128$ & 87.24 & 2.20 \\
\hline $10 X-3,74-78$ & 88.24 & 1.99 \\
\hline $10 X-4,74-78$ & 89.74 & 2.18 \\
\hline $10 X-5,24-26$ & 90.74 & 2.26 \\
\hline $11 X-1,23-27$ & 94.23 & 2.44 \\
\hline $11 X-1,67-71$ & 94.67 & 2.34 \\
\hline $11 X-2,16-20$ & 94.99 & 2.30 \\
\hline $11 X-2,123-127$ & 96.06 & 2.13 \\
\hline $11 X-3,23-27$ & 96.56 & 2.29 \\
\hline $11 X-3,73-77$ & 97.06 & 2.53 \\
\hline $11 X-3,123-127$ & 97.56 & 2.65 \\
\hline $11 X-4,73-77$ & 98.56 & 2.66 \\
\hline $11 X-4,123-127$ & 99.06 & 2.47 \\
\hline $11 X-6,23-27$ & 101.06 & 2.14 \\
\hline $11 X-6,73-77$ & 101.56 & 2.40 \\
\hline $11 X-6,123-127$ & 102.06 & 2.44 \\
\hline $11 X-7,23-27$ & 102.56 & 2.25 \\
\hline $11 X-7,73-77$ & 103.06 & 2.09 \\
\hline $11 X-7,123-127$ & 103.56 & 2.01 \\
\hline $11 X-8,23-27$ & 104.06 & 1.83 \\
\hline $12 X-1,25-29$ & 103.75 & 1.91 \\
\hline $12 X-1,74-78$ & 104.24 & 1.99 \\
\hline
\end{tabular}

Table 6 (continued).

\begin{tabular}{|c|c|c|}
\hline $\begin{array}{l}\text { Core, section, } \\
\text { interval }(\mathrm{cm})\end{array}$ & $\begin{array}{l}\text { Depth } \\
\text { (mbsf) }\end{array}$ & (\%。 PDB) \\
\hline $12 \mathrm{X}-1,125-129$ & 104.75 & 1.96 \\
\hline $12 X-2,25-29$ & 105.25 & 1.88 \\
\hline $12 X-2,74-78$ & 105.74 & 2.22 \\
\hline $12 \mathrm{X}-3,25-29$ & 106.75 & 2.34 \\
\hline $12 X-3,74-78$ & 107.24 & 2.31 \\
\hline $12 X-4,74-78$ & 108.74 & 2.39 \\
\hline $13 \mathrm{X}-1,18-22$ & 113.18 & 2.46 \\
\hline 13X-CC, $6-10$ & 113.90 & 2.46 \\
\hline $14 \mathrm{X}-1,20-24$ & 122.70 & 1.92 \\
\hline $14 X-1,72-76$ & 123.22 & 1.99 \\
\hline $14 \mathrm{X}-1,125-129$ & 123.75 & 2.00 \\
\hline $14 X-2,20-24$ & 124.20 & 1.90 \\
\hline $14 X-2,72-76$ & 124.72 & 1.60 \\
\hline $14 \mathrm{X}-2,125-129$ & 125.25 & 1.88 \\
\hline $14 \mathrm{X}-3,125-129$ & 126.75 & 1.65 \\
\hline $14 \mathrm{X}-4,20-24$ & 127.20 & 1.65 \\
\hline $14 X-4,72-76$ & 127.72 & 1.69 \\
\hline $14 \mathrm{X}-4,125-129$ & 128.25 & 1.68 \\
\hline $14 X-5,20-24$ & 128.70 & 1.73 \\
\hline $14 X-5,72-76$ & 129.22 & 1.64 \\
\hline $14 X-5,125-129$ & 129.75 & 1.67 \\
\hline $14 \mathrm{X}-6,20-24$ & 130.20 & 1.64 \\
\hline $14 X-6,72-76$ & 130.72 & 1.80 \\
\hline $14 \mathrm{X}-6,125-129$ & 131.25 & 1.73 \\
\hline $14 X-7,20-24$ & 131.70 & 1.68 \\
\hline $15 \mathrm{X}-1,25-29$ & 132.25 & 1.54 \\
\hline $15 \mathrm{X}-1,75-79$ & 132.75 & 1.58 \\
\hline $15 X-2,25-29$ & 133.75 & 1.47 \\
\hline $15 X-2,75-79$ & 134.25 & 1.56 \\
\hline $15 \times-2,125-129$ & 134.75 & 1.63 \\
\hline $15 \times-3,125-129$ & 136.25 & 1.52 \\
\hline $15 X-4,75-79$ & 137.25 & 1.53 \\
\hline $15 \mathrm{X}-4,125-129$ & 137.75 & 1.59 \\
\hline $15 X-5,25-29$ & 138.25 & 1.51 \\
\hline $15 X-5,75-79$ & 138.75 & 1.52 \\
\hline $15 X-6,25-29$ & 139.75 & 1.55 \\
\hline $15 \times-6,75-79$ & 140.25 & 1.65 \\
\hline $15 X-7,75-79$ & 141.00 & 1.69 \\
\hline $16 \mathrm{X}-1,25-29$ & 141.75 & 1.91 \\
\hline $16 \mathrm{X}-1,75-79$ & 142.25 & 2.41 \\
\hline $16 \mathrm{X}-1,125-129$ & 142.75 & 2.30 \\
\hline $16 \mathrm{X}-2,25-29$ & 143.25 & 2.01 \\
\hline $16 \mathrm{X}-2,75-79$ & 143.75 & 2.01 \\
\hline $16 \mathrm{X}-2,125-129$ & 144.25 & 2.00 \\
\hline $16 \mathrm{X}-3,25-29$ & 144.75 & 2.16 \\
\hline $16 X-3,75-79$ & 145.25 & 2.15 \\
\hline $16 \mathrm{X}-3,125-129$ & 145.75 & 2.20 \\
\hline $16 \mathrm{X}-4,25-29$ & 146.25 & 2.12 \\
\hline $16 \times-4,75-79$ & 146.75 & 2.21 \\
\hline $16 \mathrm{X}-4,125-129$ & 147.25 & 2.18 \\
\hline $16 \mathrm{X}-5,75-79$ & 148.25 & 2.25 \\
\hline $16 \mathrm{X}-5,125-129$ & 148.75 & 2.26 \\
\hline $16 \mathrm{X}-6,25-29$ & 149.25 & 2.25 \\
\hline $16 \mathrm{X}-6,75-79$ & 149.75 & 2.25 \\
\hline $16 \mathrm{X}-6,125-129$ & 150.25 & 2.23 \\
\hline $16 \mathrm{X}-7,25-29$ & 150.75 & 2.24 \\
\hline 16X-CC, $25-29$ & 151.24 & 2.31 \\
\hline $17 \mathrm{X}-1,75-79$ & 151.75 & 2.29 \\
\hline $17 \mathrm{X}-1,125-129$ & 152.25 & 2.45 \\
\hline $17 X-2,23-27$ & 152.73 & 2.61 \\
\hline $17 X-2,75-79$ & 153.25 & 2.65 \\
\hline $17 \mathrm{X}-2,125-129$ & 153.75 & 2.76 \\
\hline $17 X-3,23-27$ & 154.23 & 2.68 \\
\hline $17 X-3,75-79$ & 154.75 & 2.49 \\
\hline $17 X-3,125-129$ & 155.25 & 2.48 \\
\hline $17 X-4,23-27$ & 155.73 & 2.32 \\
\hline $17 X-4,75-79$ & 156.25 & 2.20 \\
\hline $17 \mathrm{X}-4,125-129$ & 156.75 & 2.38 \\
\hline $17 X-5,23-27$ & 157.23 & 2.33 \\
\hline $17 \times-5,75-79$ & 157.75 & 2.53 \\
\hline $17 X-6,23-27$ & 158.73 & 2.36 \\
\hline $17 X-6,75-79$ & 159.25 & 1.99 \\
\hline $17 X-7,23-27$ & 160.23 & 2.24 \\
\hline $18 \mathrm{X}-1,25-29$ & 160.75 & 1.88 \\
\hline $18 X-1,75-79$ & 161.25 & 1.72 \\
\hline $18 \mathrm{X}-2,25-29$ & 161.56 & 1.75 \\
\hline $18 X-2,75-79$ & 162.06 & 1.77 \\
\hline $18 \mathrm{X}-3,75-79$ & 163.56 & 1.65 \\
\hline $18 \mathrm{X}-3,125-129$ & 164.06 & 1.83 \\
\hline
\end{tabular}

